\title{
Kormányzástan a Laozi-ben
}

\author{
„A bölcs ember (shengren) úgy kormányoz jól...” \\ tézisének szövegértelmezése ${ }^{*}$
}

\section{Visszavonulás a közélettől - utak a taoizmusban}

„A taoizmus legáltalánosabb meghatározása ez lehetne: a közélettől való viszszavonulás ideológiája" ${ }^{-}$- fogalmaz Tőkei Ferenc a Daodejing 道德經 fordításához ${ }^{2}$ írott bevezetőjében. ${ }^{3}$ Állítása helyességének megalapozásakor az ideológia rendszerszerú kidolgozásának korában ${ }^{4}$ a kínai társadalom- és eszmetörténetben végbemenő alapvető változások tényére hívja fel a figyelmünket. E változások kiindulópontja a patriarchális családi szervezetek és az ezekre épülő, mégis ezek kisközösségi érdekeivel egyre inkább szembekerülö, bürokratikus hatalmi intézmények fokozatosan kiéleződő konfliktusa, amelynek

* Ezúton szeretném megköszönni Várnai Andrásnak a dolgozat elkészültéhez nyújtott fáradhatatlan szakmai támogatását, amellyel - mind más mellett - az egyes gondolati alakzatok jobbító kimüveléséhez járult mindig kész tevőlegességgel.

1 Tökei 2005: 12.

2 Laozi (Daodejing) I-LXXXI, Tőkei 2005, II: 17-50.

A kínai szavak latin betüs átírásakor a nemzetközi tudományos diskurzusban ma leginkább elfogadott pinyin rendszert alkalmazom. E szavak szövegkezelési minőségének jelzésére - a nem műcímet jelölő tulajdonneveket kivéve - azok dőlt betűs megjelenítése szolgál. Az egyes szakkönyvek hivatkozott, illetve idézett szöveghelyeinek formális koherenciájára törekedve a dolgozatban - amennyiben a pinyintől eltérö rendszert támogattak - azok átírásbeli egységesítését végeztem el.

3 Tökei 2005: 11-16.

4 Ennek datálása tekintetében a sinológusok véleménye között alapvető koherencia figyelhető meg, annak ellenére, hogy az egyes ókori szerzők, illetve müveik időrendi megítélésekor, különösképp a Laozi esetében, határozott eltérések jelentkeznek a kutatói álláspontokban. Figyelmen kívül hagyva tehát a szerzők kérdését, általában elmondható, hogy az i. e. V. század végén / IV. század elején első ízben megjelenő, a taoizmusra jellemző téziskezdemények, míg rendszerré formálódtak és bővültek, míg iskolává értek, csaknem száz év telt el. A taoizmus mint tanítás vagy iskola ugyanis - ahogyan Henri Maspero nyilatkozik - ,a IV. és III. század határán tủnt fel hirtelen ragyogással" (Maspero 1978: 386). 
eredeti hozadéka a bölcseletet tekintve éppen hogy a kezdeti visszavonuláselméletek megfogalmazásának szórványos és hangsúlytalan jellege volt. Míg a klasszikus viták hevében megszülető és kibontakozó nagy ideológiai rendszerek, mint a konfucianizmus és a motizmus, (már) egymással szemben és csoportérdekeiknek megfelelően, (de még) első ízben fogalmazták meg világnézetüket és ennek megfelelő politikai hitvallásukat, a tét újszerüségénél fogva egy ideig még igen kevéssé tarthatott számot szellemi befolyásra az a fajta gondolat, mely e kialakuló kereteket elutasítva a körvonalazódó problematikát egy másfajta alapról, a hivatalviselés elutasításának alapjáról kiindulva opponálta. Ezzel szemben az i. e. IV. század második felétől kezdődően a tradicionálisan szembenálló elméletek gyakorlati politikai befolyásának növekedésével, illetve az egységes kínai állam megvalósíthatóságának realizálódásával - ahogy azt a kor bölcseletet érintő vitáinak egyértelmű fokozódása és színesedése is jelzi: az alternatív nézetek szükségszerü felértékelődése miatt - járható út nyílt a visszavonulás-elméletek eredeti, spontán megfogalmazását egy - lényeges elemeiben - egységessé váló, programatikus ideológia erőterében feloldani vágyó törekvés számára. ${ }^{5}$ E törekvés legkiforrottabb és máig leghatásosabb írott terméke a Laozi 老子, más néven Daodejing: a taoista kánon reprezentáns képviselőjeként már önmagában, címében jelzi azt a szellemi mozgást, amely Konfuciusz (hagyomány sz.: i. e. 551-479) Beszélgetései és mondásai ${ }^{6}$ elvonult, magányos remeteéletet élő bölcseinek ${ }^{7}$ vagy a ,,mindenki magamagáért” elvét valló Yang Zhunak 楊朱 (hagyomány sz.: i. e. 440-360) „,naiv” antikonfucianizmusától egy olyan ideológiai rendszer kidolgozása felé tart, mely immár egy átgondoltabb argumentációra és a rendszerszerüséget biztosító tételes alapfogalmakra támaszkodik. ${ }^{8}$

A többé-kevésbé egységessé formálódó taoista ideológia több azonban, mint a hivatal elutasításának ,naiv” megfogalmazásait egy módszeres eljárás során összegző és rendszeres alapra helyező program: a Laozi lapjain a hivatal elutasításának egy paradox formájával, a „nem cselekvő tevékenység” (wei wuwei 為無為) módszerének megfelelő (kormányzati) magatartás igénylésé-

5 E bekezdés megállapításai elsősorban Tőkei Ferenc Kína e korát jellemző társadalomés eszmetörténeti fejtegetésein alapulnak (Tökei 2005: 11-13).

6 Beszélgetések és mondások (Lunyu) I.1-XX.3, Tökei 2005, I: 57-177.

Lunyu XVIII.5-9, Tökei 2005, I: 154-156.

$8 \quad$ Fung 1983 (1953): 137. 
vel találkozunk. ${ }^{9}$ Ám minden paradoxon - legyen az akár oly termékeny is, mint Laozi-é ${ }^{10}$ - feszültséget és kételyt hordoz magában; s a fogalmazás magabiztossága mögött, mely természetéből adódóan sajátja egy ilyen programírásnak, fel-felsejlik az a szellemi küzdelem, mely a „kényszerüségek” világának és a szerző ezzel szembenálló diszpozíciójának látszólag meghaladott, valójában folytonosan kísértő konfliktusából ered. Annak, hogy a müben „tanúi lehetünk a szerző hatalmas küzdelmének a jobb kifejtésért, pontosabb meghatározásért", 11 meglátásunk szerint legalább annyira oka az, hogy Laozi a bölcs uralkodóról nyilatkozva a kormányzás aktusát egyszerre akarja érvényesíteni és egyszerre felszámolni - kitéve ezáltal rendszerét az ebből fakadó nehézségeknek, melyeken ily módon igyekszik felülkerekedni -, mint az, hogy a dao 道 fogalmának meghatározásakor csupán elégtelen kifejezési módok állnak a rendelkezésére, újabb kísérletekre ösztönözve őt - ahogy azt Tőkei állítja. ${ }^{12}$ Az alapvető szövegheterogenitás olvasatra gyakorolt hatásán túl is, az iménti szempontok mentén úgy látjuk, hogy a müben kirajzolódó gondolati formák alakját és rendjét jelentősen árnyalja a szerzői álláspont kikerülhetetlenül fonák mivolta a tisztségviselés ügyében és az e fölött érzett aggodalmasság vagy kétely, mely érzés annak a sajátja, aki a falusi idillt álmodja az elitek körein belül rekedve.

Általában elmondható, hogy az elemző szem előtt két út látszik polarizálódni a taoizmus tendenciáiként: az, amelyik inkább és az, amelyik kevésbé szolgál ki hatalmi szempontokat. Ez nem azt jelenti, hogy a taoizmus maga ne lenne feltétlen ellenlábasa annak az ideológiai környezetnek, melynek kereteit a konfucianizmus klasszikus kánonja jelölte ki - ideértve a konfuciuszi tanokat bírálva továbbgondoló motista tanítást is. Csupán - a laozi-i rendszer eklektikusságának, mi több, paradoxiájának megértése szempontjából - nem hagyható figyelmen kívül annak az attitüdbeli különbségnek a ténye, mely a taoista eszmény képviselőinek a hatalmi intézmények státuszát megítélendő

9 Lásd mindenekelött Laozi III, Tőkei 2005, II: 18: „a bölcs ember (shengren) úgy kormányoz jól (zhi 治), hogy [...] megvalósítja [...] a nem-cselekvést (wei wuwei), és minden a legteljesebb rendben lesz".

10 A Laozi név nem kurzivált formájával a Daodejing ismeretlen szerzőjét vagy szerzőit jelöljük; és az utóbbi esetének lehetséges/valószínủ fennállásakor is egyes számban használjuk. Ennek megfelelően elemzésünkben a „szerző” és nem a „szerzők” alak használatával utalunk a mü vagy adott részeinek megfogalmazójára, illetve megfogalmazóira.

11 Tökei 2005: 15.

12 Tőkei 2005: 14-15. 
mutatkozik meg. Az ítélet - ahogy a kínai eszmetörténetben oly sokszor indirekt formában nyilvánul meg itt is, magatartásformák helyeslésével és helytelenítésével, minták körvonalazásával vagy épp praktizálásával, gesztusok tételével, aforizmatikus tanmesék előadásával: az égalatti sorsának kérdéséhez, így a hatalomhoz való viszonyuk különböző módjainak szövegbeli tükröződése mentén kirajzolódó alapvető distinkciónak megfelelően a hatalmi szót megvetve kerülő és az intézményi-ideológiai berendezkedést „kifordítva” folytató tendenciák különíthetők el ekként. Az előbbi útját követi a Zhuangzi 莊子 standard szövegegyüttese, míg az utóbbiét - ha némi átjárással is e kettő között - a Laozi lapjain, elemzésünk kitüntetett fókuszában találjuk meg.

\section{Programadó antikonfucianizmus}

Ha a Daodejing kormányzástanát kritikai vizsgálat alá vetjük, mind az elmondottakkal együtt és azokat megelőzően is a szöveg egy alapvető diszpozíciós státuszára irányul a figyelmünk: a taoista tanítás első intencióiban ott rejlő konfuciánusellenesség az, mely a művet kezdeteitől átjárja, fejezeteit sorra átitatja. A Laozi-beli tételek megfogalmazásakor, közvetlen vagy közvetett módon akár, mindvégig hat azok polemikus viszonya a konfuciánusok erénytani fogalomrendszere támogatta direktívával szemben. ${ }^{13} \mathrm{~A}$ hangsúlyosan antikonfuciánus fejezetek tematizmusa így elsősorban Konfuciusz tételes erényfogalmaira, a hierarchiában és a (patriarchális) családi viszonyokban kizárólagosan érvényesíteni kívánt kötelmi rendszerre reflektál kritikailag. Három fejezet a müből, a XVIII., a XIX. és a XXXVIII. passzus - mint markáns elítélő nyilatkozatai a Lunyu 論語 támasztotta elvárásrendszernek - fejezi ki leghangosabban annak vádját, hogy a konfuciánusok erőltette erény- és kormányzástan - fogalmi sarokkövein alapítva - végső soron minden felfordulás (luan 亂) felelőse: mind a családban, mind az államban. „Emberség” (ren 仁) és „,méltányosság” ( $y i$ 義), „bölcsesség” (sheng 聖) és „tudás” ( $z h i$ 智), „szülőtiszte-

13 Vö. Ivanhoe 2003: xix-xx. Erős kivételt képez ezalól a Daodejing VIII. fejezetének második bekezdése, melyben épphogy e direktívának megfelelő erénytan körvonalazódik (Laozi VIII, Tőkei 2005, II: 19). Tételei sorra idézik a Beszélgetések és mondások I/5. passzusában foglaltakat (Lunyu I.5, Tőkei 2005, I: 58), kiegészítve azt az „emberség” (ren) erényének dicséretével: végletesen ellentmondva ezzel a Laozi más szöveghelyein olvasható intelmeknek. E bekezdést összeférhetetlen szövegidegensége miatt egy esetleges későbbi betoldás eredményének tekintjük hát, és kihagyjuk a további vizsgálatunk köréböl. 
let” (xiao 孝) és „,gondoskodás” ( $c i$ 慈), (mímelt) „hüség” (zhong 忠) és (felszínes) ,bizalom” ( $x$ in 信), legfőképpen pedig a „szertartásosság” ( $l i$ 禮): az oly megbecsült konfuciánus erények tételes elutasítása e fejezetekben az égalatti eredeti rendjét adó dao elveszejtésének bírálatával együtt kerül kifejtésre, súlypontilag jelezve, hogy az úgynevezett erények egyenként és együtt is - ahogy a konfuciuszi tanításban rájuk találunk - csupán egy megváltozott, erényvesztett állapot kifejeződései, a wen 文 -civilizáció termelte silány pótlékok a magától való (ezért magától értődő), természetes emberi viszonyokkal szemben, melyek esetében mind az előbbi megfogalmazása teljesen szükségtelen és bosszantóan müvi.

A daót odahagyó ren és yi, a (konfuciánus) „bölcselkedés” képmutatása, a családokat dúló békétlenségre adott őszintétlen válaszok: xiao és $c i, \mathrm{~s}$,alkonyórán” a puszta „haszonszerzés” ( $l i$ 利) céljából önös érdekeiket követő, „hüséges alattvalók” megjelenése, a XVIII. fejezet e kritikus motívumsora ${ }^{14}$ szorosan egyeztetett a rákövetkező passzus „pozitívan tételező” bírálati modelljének az elemeivel; és részleteivel ugyancsak beleillik a XXXVIII. fejezetben - spekulatív módon - ábrázolt, a (taoista) „erényesség” elvesztésének a folyamatát leíró sematizmus tételei közé. Hogy ez utóbbi vizsgálatát vegyük előre, indokolja a két leírás azonos iránya: egy széles körü devalváció tapasztalata, rögzítése.

A folyamat, melyet a XXXVIII. passzus lépéseiben tár fel, kétszeresen kifejtett az adott szöveghelyen, ezek szegmenseit tekintve azonban konzisztens: (1) a daóhoz közel álló „magas erény” (shangde 上德) nem (konfuciánus) erény (bude 不德), ezért „erényes” (youde 有德) - nyitja a sort Laozi a (taoista) erény paradox dicséretével. A shangde ezt követő elvesztegetésén, baljós feladásán terem aztán (2) a párhuzamos leírásban csupán de-ként 德 jellemzett „alantas erény” (xiade 下德) önhitt gyakorlata, mely erény nem „erényes” (wude 無德) azonban, hisz nem hagy fel a (konfuciánus) erényre való törekvéssel (bushide 不失德) - hangzik az „Öreg mester” ${ }^{15}$ szintén paradox bírálata. Később pedig, ha minden ,erény” letünt már, következhet a sorban (3) az „emberség” átfogó kötelméhez való igazodás konfuciánus előírása; majd annak is feladását követően (4) a puszta „,méltányosságban” megállapított hatalmi-közéleti relációk egyszerü - de erélyes - követelése. Az erénytani lejtmenet végén - ahogy Laozi látja - (5) a „,szertartásosság” kiüresedett elvárás-

14 Laozi XVIII, Tőkei 2005, II: 22.

15 Laozi nevének szó szerinti jelentése. 
rendjének szoros kikényszerítése áll. ${ }^{16}{ }$ Márpedig a szertartásosság: a hüség (zhong) és bizalom (xin) külső héja csupán; s minden felfordulás kezdete"17 - azonosítja hát a szerző a konfucianizmust mint korok elveszejtöjét, a fennálló visszás állapotok előidézőjét.

A tendenciózus leírások „pozitív” párjaként a XIX. fejezet regresszív kiútkeresése - ahogy említettük - az azt megelőző fejezet mintázatának vonalait követi tételeiben, bírálata azonban elöremutató. A sheng és a $z h i,{ }^{18}$ illetve a ren és a yi elvetését sürgeti Laozi a nép „hasznát” (li) szem előtt tartandó, illetve annak érdekében, hogy a konfuciánus fogalmakkal ácsolt erények közül azok, melyek alapja naiv-vitális közösségi viszony - ilyen a xiao és a $c i-$

16 Laozi XXXVIII, Tőkei 2005, II: 29-30.

17 Laozi XXXVIII, Tőkei 2005, II: 30. Bár konfuciánus kontextusban a felszínesség és alakoskodás laozi-i vádjával terhes, a zhong (,hüség”) és xin („,bizalom” vagy „,szavahihetőség”) erénypárjának bizonyos fokú rehabilitációját tapasztaljuk itt. Annál is inkább lehet így, mert - ellentétben más Lunyu-beli erények Laozi-beli megjelenésével - (legalábbis) a xin fogalma ismétlődőn és pozitívan tételezett a müben. Jelentésmódosulását azonban nem hagyhatjuk figyelmen kívül: elsősorban az „elegendő bizalom” (zuxin 足信) „,bizalmatlanságot” (buxin) megelőző-hárító tulajdonságát értékeli a szerző (Laozi XVII, XXIII, Tőkei 2005, II: 22, 24). Teszi ezt oly mértékben továbbá, hogy azzal mégis és újra csak - ahogy látjuk - a konfuciánus tanokat állítja pellengérre: „Én hiszek (xin) a megbízhatóaknak (xinzhe 信者), s ugyanúgy hiszek (xin) a megbízhatatlanoknak (buxinzhe 不信者) is; (így) nyerek bizalmat (xin)" - tanítja a XLIX. fejezetben (Laozi XLIX, Tőkei 2005, II: 33; vö. többek közt Lunyu II.22, Tőkei 2005, I: 64). A xin fogalmának átértékelése annak paradox kiterjesztése tehát, azaz konfuciánusellenesség.

18 A „bölcsesség” és a „tudás” mint társadalomszervező erők taoista elutasítottságához a következőket érdemes hozzáfüzni: először is a sheng fogalma önállóan (azaz a shengrentől elválasztva) csakis ezen a helyen szerepel a müben, így megengedhetővé válik, hogy a zhi jelen párjaként (aktuális) jelentése ahhoz közelítő, azzal szinonim viszonyba kerülő legyen. Fontos ez azért, mert maga a taoista tanítás is a sheng fogalmával jellemzett: ennek esetleges feladásáról itt - mint problematikáról - azonban kevéssé lehet beszélni. Másodsorban a sheng és a zhi mégsem a Lunyu talaján találkozik, ha összekötjük öket, hanem a későbbi konfuciánusok (és motisták) müvei mentén: egyszerüen azért, mert - bár a sheng fogalma már a Beszélgetésekben és azt megelőzően is kitüntetett - a zhinek megfelelő ,tudás-bölcsesség” fogalma ebben a formában Mozinél 墨子 (hagyomány sz.: i. e. 470-391) jelenik csak meg, a Lunyuben még nem. A konfuciánus Mengzinek 孟子 (i. e. 372-289) köszönhetően emelkedik aztán a legfőbb erények rangjára, amint tanítja: „A nemes ember (junzi 君子) természetének az emberséget (ren), az igazságosságot [a méltányosságot] (yi), a szertartásosságot (li) és a bölcsességet (zhi) tartja" (Mengzi VIIA: 21, Tökei 2005, I: 377). Innen, ebből a perspektívából éri Laozi antikonfuciánus bírálata e fogalmi kettőst és veti el a „tudást” (ezen túl is) mint a nép megkárosítóját - ha részesül belőle: kormányozhatósága nehezékét (vö. Laozi LXV, Tőkei 2005, II: 40). 
újra érvényesüljenek eredeti szerepükben: elérve ezáltal a családi viszonyok harmonikus visszarendeződését. A „müveskedés” (qiao 巧) és a „haszonlesés” (li) elítélését, elhagyását pedig a vagyonszerzés fékezhetetlen vágyából ( $y u$ 欲) adódó, közösséget feszítő, destruktív tendenciáktól való megszabadulás követhetné a tanítás szerint. ${ }^{19}$

E tanítás letéteményese, annak remélt beteljesítője: ő az, aki a laozi-i taoizmus első embereként a maga képességét, hatását az égalatti viszonylatában - elvárhatóan - ideális módon képes kifejteni. ${ }^{20}$ Hogy a Daodejing szerzője - kiutat remélve tehát a konfuciánusok direktív mintaadásának vélt repressziója alól - „bölcs emberétől” (shengren 聖人) a teljesség mely kritériumait kívánja meg, erre keressük a választ a következőkben.

\section{A shengren kormányzáshoz való viszonya}

Ha röviden kellene válaszolnunk a korszakos kérdésre, miszerint „az égalatti kívánt rendjének biztosítása érdekében miként, mihez igazodva járjon el a tanok megszólítottja, ideáltipikus személye", a Laozi intenciójával azt mondhatnánk: a daónak való megfelelésben születik a bölcs ereje (de) az égalatti rendjének elősegítésére. ${ }^{21} \mathrm{~A}$ mű XIX. fejezetének - az előzőekben vizsgált első felét követően, a wen-műveltségen való élcelődés mentén vázolja fel Laozi azokat a taoista mintákat, amelyek követésre hívásával a kényszerü kötelmi viszonyok felszámolását igyekszik elösegíteni. A dao e közelítése: bao $p u$ 抱樸 (,a faragatlan [fa] ölelése”), shao si 少私 (,a törekvés gyengítése”), gua yu 寡欲 (,a vágyak mérséklése”). ${ }^{22}$ Ezek alapvető gyakorlásában eredezteti tehát a szerző a harmonikus közösségi érintkezések felelevenítésének egyetlen (értsd: nem konfuciánus) lehetőségét.

19 Laozi XIX, Tökei 2005, II: 23. Az utóbbiakkal kapcsolatban lásd még Laozi III, Tökei 2005, II: 17-18: „Ha nem tartják nagyra a nehezen megszerezhető vagyontárgyakat (huo 貨), akkor a nép közt nem lesz többé rablás.” Továbbá vö. Laozi LVII, Tökei 2005, II: 36: „minél több ember lesz ügyes mester (ji qiao 伎巧), annál több ritka tárgyat <árut> találnak fel; s minél több a törvény és parancs, annál jobban elszaporodnak a rablók és tolvajok”. A „törvény” fogalmának értelmezéséhez lásd Creel 1970: 83. Vö. Kósa 2013: 174: „a Daodejing részben az ideális uralkodás megvalósításához írt »kézikönyv«".

21 Ezt kiegészítendő vö. Max Kaltenmark szövegértelmezésével, miszerint: bár a dao megragadhatatlan, az Út mégis járható (Kaltenmark 1969: 93-95).

22 Laozi XIX, Tökei 2005, II: 23. 
A „faragatlan (fa) egyszerüsége” (vagy kínai tömörséggel: a $p u$ 樸) mint mintázat olyan habitus felvételét feltételezi, mely egy vitális-eredeti irányultságban az ember elemi vonatkozásait képezi le - mind társas, mind egyéni szinten. Ez a habitus - szándékai szerint - messzemenőkig ellenáll a wenmüveltség müvi tekintélyének, cirkalmas, túlszabályozott elvárásrendszerének. Ezzel pedig - s hogy a daónak leginkább megfelel - alkalmassá válik arra, hogy az embereket visszavezesse eredeti egyszerüségükhöz, megszabadítva őket káros terhüktől: wen-civilizációs normák hiábavaló követésétől - szól a tanítás ennek elérését célozva. A pu mintázata szorosan feltételezett és rendre együtt jár - ahogy az elöbbi szöveghely is mutatja - a ,vágyak mérséklésének és elhagyásának" (gua yu / buyu 不欲 / wuyu 無欲) daohü indítványával. ${ }^{23}$ Ezek kettőse ellenállhatatlan erejü: „A névtelen [ti. a dao] egyszerüsége (wuming zhi pu 無名之樸) éppen abban áll, hogy egyáltalában nincsenek vágyai (wuyu). Nem vágyakozni (buyu) pedig: nyugalom; és az égalattiban magától helyreáll a rend"24 - olvashatjuk a XXXVII. fejezetben a vezetői karizma (de) taoista emanációjának dicséreteként. A Daodejing kormányzástana szempontjából pedig elsődleges jelentőségü e hatásmechanizmus: a karizmán keresztül érvényesülő, kihatásában magabeteljesülő mintaadás; ${ }^{25}$ amely gondolat - ahogy itt látjuk - pu és buyu/wuyu fogalompárjával keretezett.

23 Az intenzív fogalmi kapcsolódás a $p u$ és a gua yu stb. között a következő fejezetekben figyelhetö meg: Laozi XV. (pu és buyu), XIX. (pu és gua yu), XXXVII. (pu és wuyu/buyu), LVII. (pu és wuyu), Tökei 2005, II: 21, 23, 29, 37. Vö. Laozi XXXIX, Tőkei 2005, II: 31: a „csiszolatlan (jáde) kő-egyszerüségének (megtartása)” (luo-luo 珞珞) és a „csiszolt jáde ékszer-fenségéről való lemondás” (buyu lu-lu 不欲淥淥) magatartási mintákként hasonló fogalmi relációban alapítottak, mint az előzőek.

25 Lásd még Laozi XXXII, Tőkei 2005, II: 28: „Ha a fejedelmek és királyok (houwang) képesek rá, hogy megőrizzék [a daót], akkor minden létező (wanwu) magától fog hódolni nekik [...], a nép pedig minden parancs (ling 令) nélkül, magától megnyugodna”, illetve Laozi LVII, Tőkei 2005, II: 36-37: „Ha én [a bölcs ember] nem-cselekvő vagyok (wuwei), akkor a nép magától megváltozik; ha én szeretem a nyugalmat, akkor a nép magától megjavul; ha nekem nincs tevékenységem [nincs ügyem] (wushi 無事), akkor a nép magától meggazdagodik; s ha nekem nincsenek vágyaim (wuyu), akkor a nép magától visszatér a faragatlan fa állapotába (pu)." Érdemes megfigyelnünk, hogy e tanítás - bár részleteiben többször elkülönbözik a Lunyu-beli tanoktól - a „hatás mint magától való beteljesülés" teóriája mentén szorosan párhuzamba állítható az uralkodó/junzi karizmatikusságát hirdető konfuciuszi iskolával (vö. Lunyu II.1, XII.18, XIII.4, Tőkei 2005, I: 60, 117, 120). Az alapvető hatalomtechnikai (egyben ideológiai) elkülönbözéssel: a „parancs” (ling/ming 命) szükségességének vagy szükségtelenségének problematikájával kapcsolatban pedig vö. újra Laozi XXXII, illetve LI, Tőkei 2005, II: 28, 34 és Lunyu XIII.3, Tökei 2005, I: 120 (,a nemes ember olyan neveket 
A pu egy másik párja a daóval való közösségben: a ziran 自然 („magaolyanság”) - mint fogalom és mint bölcseleti alapvetés a laozi-i tanítás egy elméleti sarokköve. Hasonlóan a „faragatlan (fa) egyszerüségének” fogalmi irányultságához a ,maga-olyanság” tétele is a dolgok és magunk megmásítatlan eredetiségéhez való elemi-evidens hozzáférésünket (leginkább az uralkodóét) igyekszik felidézni; azért ugyanis, hogy az abban rejlő potenciált, a környezetünk viszonyainak vágyott originalitását - ekképp egyensúlyát - magából kidolgozza. A pu jelentette mintázat szimplicitásától eltérően azonban a Daodejing szerzője mintegy vonatkoztatási rendszert alapít a ziran fogalmában; ettől válik érvényessé - sok más mellett - a „faragatlanság” pozitívuma is mint a dolgok „maga-olyansága” szerint való, de lám, ebben gyökerezik minden rend s még a dao is: „Az ember [...] [a földet] követi, a föld [...] [az eget] követi, az ég [...] [a daót] követi, a dao pedig [...] [a maga-olyanságát] (ziran) [...] követi" ${ }^{26}$ - mondja Laozi. Ziran és $p u$, pu és buyu: megegyezésben a daóval hát a shengrent a kormányzáshoz való viszonyának különböző útjain egyként elkíséri; és ami társul még ehhez, az elkövetkezőben jegyezzük.

A Laozi II. fejezetében ugyanis - mintha olvasati támogatásul - egy rendszeres előképét kapjuk a shengren karakterisztikájának: az alapvető, rájellemző fogalmak, wuwei 無為 és buyan 不言 bevezetésével - figyelmünk további meghatározóival. Ezek: a „szolgálattételekben” (shi 事) megnyilvánuló (hivatali) tevékenység mint hatalomgyakorlat felfüggesztése (wuwei) és a (taoista) „tanítás” (jiao 教) „,beszéd nélküli” közvetítése (buyan). Az érdeknélküliség mint a taoista bölcs erényalkatának lényegi tulajdonsága válik még hangsúlyossá e szöveghelyen, és valami olyasmi emellett, ami végigkíséri e karaktert a müvön: mint az iméntiek - wuwei és buyan - által is táplált (látszólag) feloldhatatlan kettősség. Ennek alapeseteként a következőt olvashatjuk itt: a bölcs „létrehoz”, azaz „szül” (sheng 生): belőle indulnak ki „müvek” (gong 功), s azok hatásában jelen van bár, nem kötődik hozzájuk ( $f u j u$ 弗居). ${ }^{27}$

A mindent alapjaiban érintő laozi-i kettősség a kormányzáshoz való viszonyulás első-eredeti aspektusaiban is megjelenik: „tanító” vagy „vezető” - együtt és külön-külön is paradox - kettőse jellemzi a shengren Daodejing-

ad [...], hogy azokat mindig mondani [...] is lehessen, és kimondva őket, mindig [nekik megfelelően] cselekedni lehessen").

26 Laozi XXV, Tőkei 2005, II: 25. A fentiekkel szorosan egyeztetve vö. Liu 2009: 227. A tétel további értelmezéséhez lásd Várnai 2018: 69.

27 Laozi II, Tökei 2005, II: 17. 
beli karakterét. Paradoxon: hiszen az, aki tanít, de mint buyan, ${ }^{28}$ vezet, de mint wuwei, ${ }^{29}$ vagy épp tanítana, de visszavonultan - míg máskor vezető lenne: a hétköznapi racionalitással mit sem törődik - egyszerre emelkedik felül azon, s egyszerre ás le annak gyökeréig (mint majd látni fogjuk). A duális szemlélet és mind e jellemzők érvényesülése mentén a szövegolvasati kapacitásban négy egymásba hajló, ám jól felismerhető út körvonalazódik, amelyek a shengren egy-egy mélyebb attitüdjét jelenítik meg az égalatti kormányzásával összefüggésben: (1) a közélettől magányába zárkózó, hatását tanításában kifejtő bölcs útja; (2) a fejedelmek mellett segédkező, erényes (had)vezető tisztségének megfelelő út; (3) a „,bölcs emberré” lett uralkodó útja; (4) az uralkodóvá lett „bölcs ember” útja. Lássuk hát részleteiben - kifejtésünkben a fejezeti relevancián szisztematikusan építkezve -, hogy a shengren által bejárt utak $^{30}$ hogyan alakítják ki a laozi-i kormányzástan egy komplex-heterogén rendszerét.

28 Erről bővebben lásd Várnai 2011: 16.

Konfuciusz a Beszélgetések egy helyén a fentivel összhangban ugyancsak megjegyzi - lássuk az újabb párhuzamot -, hogy - mivel a de nem a szavakon keresztül hat - a junzi-nek aligha a beszédével kellene hatást gyakorolnia (Lunyu XVII.18, Tökei 2005, I: 151: „A legszívesebben nem beszélnék [wuyan 無言]. [...] Hát az Ég beszél? A négy évszak megy a maga útján, a dolgok [bowu 百物] megszületnek. Beszél-e az Ég?"). A Lunyu- és a Laozi-beli kormányzástan legjelentősebb párhuzamos tanítása az (uralkodói) tett-tétlenség (wuwei) gyakorlásának mintaszerü leírása. Ebben a tett-nélküliség szakrális „mozdulatlanságra” hív - kiváltképp a konfuciánus metódus esetén. S épp, mert az uralkodó „mozdulatlan” vagy a „bölcs ember”, ki tétlen - Laozi visszatérő mondásával élve -, „nincs olyan, amit ne tudna megtenni” (Laozi XXXVII, XLVIII, Tőkei 2005, II: 29, 33). Vö. ennek értelmében Lunyu II.1, Tőkei 2005, I: 60: „Aki erényével (de) gyakorolja a kormányzást, az olyan, akár az északi sarkcsillag, amely mozdulatlanul a helyén marad, bár minden csillag mozog körülötte”, illetve Lunyu XV.4, Tőkei 2005, I: 136: „Shun 舜 olyan uralkodó volt, aki tevékenység nélkül (wuwei) is jól kormányzott. Hogy mit tett? Semmi mást, csak komolyan ügyelt önmagára, és példamutatóan fordította délnek az arcát [...]." Az „emberek urának” (ren zhu 人主) segítőjeként megjelenő shengren útjának, azaz a (2)-es pontnak bővebb kifejtésére - kevésbé hangsúlyos tartalmi jellegére való tekintettel - a jelen dolgozat keretei között nem nyílik mód. E tárgyban a mű vonatkozó fejezetei a következők: Laozi XXX, XXXI, XLI, LXVIII, Tőkei 2005, II: 27, 31, 41. További részletekért lásd még Rand 1979-1980: 181-182. 


\section{A shengren mint visszavonult bölcs}

Az „Öreg mester” egyedülálló személyes példamutatása a XX. passzus, amely leírásnak fanyar íze egyfelől gyengíti a szöveg amúgy határozott állásfoglalását, másfelől támogatja annak paradox tartalmiságát: a kormányzásra való utalásában épp annak hiánya figyelhető meg itt. A shengren prototípusa, a szerző maga - ahogy e passzus megrajzolja e karaktert - apolitikus, aszociális személyiség. Kormányzáshoz, más emberek vezetéséhez vajmi kevés köze van. ${ }^{31}$

Ráadásul nemcsak, hogy apolitikus Laozi e személyes bölcsfigurája, határozottan, ismételgetve állítja, hogy egyedüliként, szoliter magányában áll, „,kitüntetettként” a többi ember között - közel állva ahhoz, hogy kizárja lehetőségét mások shengrenné válásának (,,csak én vagyok más, mint a többi ember: én az Anyából való táplálkozást tartom a legtöbbre”; „,csak én vagyok maga a homály”; „,csak én vagyok mozdulatlan” stb. ${ }^{32}$ ): egyértelmü nyilatkozat a dao bölcsének egyedisége, egyedülisége mellett. ${ }^{33}$

Egyetlen soros, ámbár többször - több formában - elhangzó kifakadása (,Ó mily zürzavar [dun dun 沌沌]!”34) jelzi azonban, hogy az állapot, melyben ő maga és az égalatti leledzik - ahogyan ő látja - instabil, és annak jólrendezettsége hiányában változásra érett: szoliter magánya, erénye egyedisége, elszigeteltsége ideiglenesnek tekinthető tehát, így a shengrenlét kizárólagossága mégiscsak megdőlni látszik.

Aki ,jól tudja irányítani az életét”, azon ,nincs halálos hely”, mivel „nem táplálja oly bőségesen az életét”, mint mások ${ }^{35}$ - mondja az L. fejezet utalva arra, hogy aki így él, a dao szerint él, vagy fordítva: aki a dao szerint él, az itt leírtak szerint él. A leírást, e taoista miszticizmust, azonban itt sem jellemzi egy uralkodói alak megjelenítése: inkább egy - a tanítást praktikusan elsajátító - arra hivatott emberéé. Laozi megszólítottja tehát ezen a helyen is a

31 Vö. ezzel szoros párhuzamban a bölcs Zhuangzi-beli megjelenését (lásd sokak mellett pl. Zhuangzi I.2, Tőkei 2005, II: 59).

32 Laozi XX, Tökei 2005, II: 23.

33 Vö. Laozi XLIII, Tökei 2005, II: 32: „Ám a szavak nélküli tanítást és a nem-cselekvés hasznát az égalattiban csak nagyon kevesen érik el <értik meg>", illetve Laozi LXX, Tökei 2005, II: 41: „Az égalattiban mégsem tudja megérteni senki, mégsem tudja megvalósítani senki (a tanításomat).” Továbbá vö. megfelelésben a Lunyu releváns paszszusaival.

34 Laozi XX, Tőkei 2005, II: 23. Vö. Chan 1963: 149: „But, alas, how confused...”

35 Laozi L, Tökei 2005, II: 34. 
hivatali hierarchia minden vonatkozásától érintetlen erényes ember, aki ilyen értelemben nem részese politikai-hatalmi kérdéseknek. E megállapítást alátámaszthatja az az észrevétel is, miszerint a vonatkozó (kifejtö) leírás során az erény (de) kiterjesztésének, közvetítésének önbeteljesítő feladatáról szó sem esik - még utalás szintjén sem; ami azonban atipikus a Laozi esetében, ha ugyanis egy shangshi 上士 (,felettes írástudó”) ${ }^{36}$, főleg ha az uralkodó erényéröl nyilatkozik.

Az LV. fejezet elhivatottja - bár személye éppúgy misztikus - a „de teljességének (hou 厚) birtokosa", kinek jellemzését Laozi itt mintaként elénk tárja: a megelőző, LIV. fejezet fogalmi rendszeréből következően ${ }^{37}$ az égalatti vezetője is lehetne. Leírása azonban a bölcsre általában jellemző meghatározásokkal történik: „újszülötthöz” (chizi 赤子) hasonlatos, talpraesett, egyszerüségében, „egy-ügyüségében” teljes, az ,életerő (jing 精) legmagasabb fokával” bír stb. ${ }^{38}$

Megjegyezzük tehát, hogy ez a passzus is azon fejezetek közé tartozik, amelyek apolitikus indíttatásúak. Érdemesük bár (a várva) a „daóba helyezkedett", ám mint politikai karakter nélkül való: lehetne épp vezető is, de ugyanúgy - legalábbis hasonlóképp - lehet bárki más. A fejezetnek ezt a jellegét a második bekezdés fordított irányú érvelése erősíti, hiszen itt már a tanítással való esetleges szembenállásról s ennek negatív következményeiről szól Laozi - feltételezve, hogy a minta, a „,e birtoklása” szabadon kapacitált: „Aki pedig nem a dao szerint él, az korai halállal pusztul el. ${ }^{\text {} 39}$

Habár trónusról és uralkodóról, az Ég Fiáról (tianzi 天子) és „,három főemberéröl” (sangong 三公), ezek tiszteletéről szól Laozi a LXII. fejezetben - ezáltal e tisztségeket és (amint olvashatjuk: „tiszteletre méltó tettekkel lehet hivatalt szerezni" ${ }^{40}$ ) hivatali mechanizmusokat tart itt érvényben - alternáción, erőteljes, pimasz relativizmuson érjük őt tetten, mikor a daót - hangsúlyosan a „rossz emberek” támaszaként (is) kitünteti, ${ }^{41}$ megvalósítva ezzel a „titokzatos

36 Lásd erröl Laozi XLI, Tökei 2005, II: 31.

37 Laozi LIV, Tőkei 2005, II: 35.

38 Laozi LV, Tőkei 2005, II: 35-36.

39 Laozi LV, Tőkei 2005, II: 36.

40 Laozi LXII, Tőkei 2005, II: 38. Még ha gúnyolódónak is tekintjük itt egyes megjegyzéseit, hol vannak ezek a más fejezetekben - pl. a III.-ban a „kiválóság” (xian) elítélése kapcsán - oly markánsan elkülönbözö tételeinek alapvetéséhez képest (Laozi III, Tökei 2005, II: 17)?

41 Laozi LXII, Tökei 2005, II: 38: „A dao: [...] a jó embereknek (shanren) kincse, a rossz embereknek (bushanren) oltalmazója.” Ennek megfelelően lásd még Laozi XLIX, 
azonosítást" (xuan tong 玄同). ${ }^{42}$ Laozi - merész tisztelete jeleként, mely mármár sértésig jut - „drágakőkorong” és „négyes-fogat” helyett „,ezt a daot [küldené] be (a palotába)"43. Hogy csúfot üzne az uralkodóból azonban, s ilyenképp hasztalansággal vádolná öt, továbbra sem tünik fel realitásként, hisz tanai, a dao ereje - melyet a legkülönb ajándékként kínál az Ég Fia számára (is) - biztosítja a tartósságot, és legyőzhetetlenné tesz - miként állítja. ${ }^{44} \mathrm{~A}$ felajánlás viszonyjellegéből ellenben következik egy újabb megállapítás, mely okot adhat majd a később előadottakban bizonyos hangsúlyok felülvizsgálatára: Laozi, a bölcs, nem wang 王 („király”). Nem is aspiráns. Még csak nem is föember. Bármely hivataltól, minden közélettől távol maradónak látszik: „otthon maradónak” ${ }^{45}$ - ahogy a Tőkei-féle fordításban mint értelmező kiegészítés olvashatjuk. Hogy e sorok valóban a szerzó által ténylegesen ${ }^{46}$ elfoglalt pozíciókról, egyáltalán a szerző pozícióiról tájékoztatnak, a kifejtés módja miatt - lévén bizonyos egyéb szöveghelyekkel ellentétben a közlés itt nem egyes szám első személyben történik - csak erős valószínűséggel állítható. Ha azonban elfogadjuk ezt az állítást - márpedig számos passzus egy ilyen szerzői portrét támogat -, első (és talán egyetlen) alkalommal találkozhatunk egy szövegrészen belül a dao erényesével - méghozzá Laozi személyében - és a trónt ülő wanggal, az Ég Fia fenségével, mint két, egymástól aktuálisan jól megkülönböztetett (és egymással interakcióban álló ${ }^{47}$ ) karakterrel: innen e közlés kitüntetettsége, ereje.

Tőkei 2005, II: 33: „Én <a bölcs> a jókkal (shanzhe 善者) jól bánok (shan 善), s jól bánok (shan) a rosszakkal (bushanzhe 不善者) is; (így) szerzek jóságot (shan).” Szigorú ellentétben az iméntiekkel vö. Laozi LXXIX, Tőkei 2005, II: 44: „Az égi dao [...] mindig a jó ember pártján áll."

42 Lásd erről Laozi LVI, Tőkei 2005, II: 36: ..tompítani minden élességet, megoldani minden csomót, mérsékelni minden ragyogást, elegyengetni (tong 同) minden port: íme, ezt nevezzük titokzatos azonosításnak (xuan tong)". Vö. Laozi IV, Tökei 2005, II: 18: „Tompít minden élességet [ti. a dao], megszüntet minden zavarosságot, mérsékel minden ragyogást, egyesít (tong) minden porszemet."

Laozi LXII, Tökei 2005, II: 38.

Laozi LIV, LIX, Tökei 2005, II: 35, 37.

Laozi LXII, Tökei 2005, II: 38. Vö. Laozi XLVII, Tökei 2005, II: 33 és Wu 1989: 27. Az adott fennállás csak a mü körén belül értelmezendö. A történetiség szempontjából inadekvát.

A bizonyos fokú megkülönböztetettség, a két karakter azonos fejezeten belüli szerepeltetése más szöveghelyek - kiváltképp a XXXVII. passzus - esetében is megvalósul, a jelen leírásban rejlő egyfajta többlet azonban, miszerint e szereplők között egyidejü kapcsolat áll fent - ha mégoly elvont is -, egyértelmüvé teszi a megkülönböztetés jellegét: fogalmuk - legalábbis az itt közölteknek megfelelően - nem vált át egymásba. 
Azután: a LXIV. fejezet, bölcsességek egy tablóba rendezett (kép)sora, a shengren profilját megrajzolva - akárcsak az azt megelőző passzus ${ }^{48}$ - alapvetően és újra csak apolitikus vonásokkal társítja azt. Jól látható ez pusztán már abból a körülményből adódóan, hogy egy valóban átfogó, a legelső jellemzőket taglaló képleírás során a shengren politikai-közéleti szerepvállalásáról vajmi kevés szó esik; az a kevés is inkább csak - karaktersajátosságainak megfelelően - a de hatásában állapítja meg e jelenlétét: „Így segíti elő, hogy a dolgok (wanwu 萬物) megmaradjanak [...] [maga-olyanságukban] (ziran)". 49

A LXX. fejezet újabb önvallomás a szerző egyedülvaló bölcsességéről és megélt különbségéről, elkülönüléséről - e képessége folytán. Nyilatkozatában feltehető legitimitásigénye sarkallja, hisz érvei tanítása megalapozottságát és mintegy természetességét hangsúlyozzák, retorikájában pedig a tekintélyelvüség uralkodik: ,,szavaimnak van őse [...], tetteimnek van ura" ${ }^{, 50}$.

Magát mint shengrent mutatja be, a kevesek egyikét vagy talán az egyetlent (ha abból indulunk ki, amit a fejezet első felében állít, miszerint az égalattiban senki sincs, aki tanítását megértené és követné, feltétlenül ez utóbbi lehetőséget kell érvényesnek tekintenünk ${ }^{51}$ ). A „,bölcs ember” képe tehát, mellyel itt szembesülünk, kevéssé uralkodói. Inkább hat tanítónak. Megértést vár, tanítása fontosságát hangsúlyozza ahelyett, hogy - várhatnánk - erénye misztikus többlete révén egyszer csak megvalósítaná a dao uralmát az égalattiban. A visszavonult, tanítói attitűdöt erősíti az a szembeállítás is, miszerint előkelőségének ékszereit „durva ruha alatt”, „keblében” viseli; ugyanakkor e visszafogott, láthatatlan ragyogás egyként erénye a taoista uralkodónak is. Legyen bármi is a shengren státusza itt, hogy híján van értő füleknek, taní-

48 Laozi LXIII, Tökei 2005, II: 38-39.

49 Laozi LXIV, Tőkei 2005, II: 39. Az „,égalatti dolgainak” egymást feltételezéséről lásd Robinet 1997: 97-99.

50 Laozi LXX, Tőkei 2005, II: 41.

51 Lásd 33. lábjegyzet. A hivatkozott laozi-i sorok, e végletes és kizáró beszédmód rigid, szó szerinti értelmezésén túl könnyen adódik a lehetőség, hogy azt, mármint e beszédmódot, túlzó jellegü, retorikus eszköznek tekintsük inkább, mellyel a szerző ügye hangsúlyozásának érdekében él: ha így van, e kijelentéseket nem elsősorban mint szabatos állításokat, hanem mint a figyelmünket ekként irányító szuggesztiókat értékelhetjük. Ennek megfelelően a shengren magánya - ahogy itt látjuk - nem szükségképpen jelentené erénye birtokának tényleges kizárólagosságát - szemben fenti állításunkkal. Továbbá vö. Laozi LXXVIII, Tőkei 2005, II: 44: „Hogy a gyenge mindig legyőzi az eröset, a lágy pedig legyőzi a szilárdat, azt az égalattiban mindenki tudja, de nincs senki, aki meg is tudná valósítani." 
tására fogékony erényeseknek, ehhez - a mondottak értelmében - kétség sem férhet. A fejezet második felében tett megjegyzése, korrekciója nyomán sem tér el ettől számottevő mértékben - épp csak tanítása elevenségét (egyben erénye alapjait) igyekszik biztosítani, rögzíteni, mikor állítja: „Nagyon kevesen értenek meg engem, de éppen ebben rejlik értékem." ${ }^{, 52}$ A megértés e hiányának magyarázata - ahogy a szövegrészek kontextuális olvasatából ez adódik - a Laozi első és alapvető különbségtételének, szembeállításának azon mozzanatából indulhat ki, melyben a müvileg tett elválik az egyszerüségében adottól, a civilizáció kénye és kényszere a magától értődő (falu)közösségi lét romlatlanságától. Az értetlenség eszerint a - tágabb értelemben vett - kortársi gondolkodás és szemlélet - valami „eredetihez” képest - megváltozott alapjaira utal, arra ugyanis, hogy a hivatkozás rendje - társas érintkezések, berendezkedések alapja - „többé” már nem a daóra megy vissza (vagy ami ugyanaz, a „maga-olyanságára”), ahogy tette volna eddig - kimondatlanul is, kifejtetlenül is -, hanem konfuciánus erények, civilizációs vívmányok művi tekintélyére, melyek megerőszakolva az ember vitális egyszerüségét, tévútra vezetik azt: innen tehát az értetlenség - így értjük meg. Mindezek után és értelmében két erős, egymással szembemenő állítást fogalmazhatunk meg a fejezet kapcsán: (1) a szerző korának embere - ahogyan ö látja - a xiashi 下士, az „alantas írástudó”, aki a taoista tanítás érvényét felismerni s azt követni képtelen (hasznát lesi folyton csak, a valódit ezért elvéti); (2) a különbség révén azonban, amely az „Öreg mestert” és a „keveseket” megkülönbözteti az iméntiek sokadalmától, mégsem lesz hatályos a mü hangsúlyos tétele - ha

52 Laozi LXX, Tőkei 2005, II: 42. Az érdemek ilyen megszerzését egyébként - akárcsak itt - a XV., a XVII. és a XLI. fejezet tanúsága szerint is a megismerés vagy elsajátítás képességének valamiféle korlátozottsága teszi lehetővé. Ezek közül az előbbiek esetében a vezetők és uralkodók megkülönböztetett erénye múlhat „kiismerhetetlenségükön”: jelenlétük ugyanis áldásos, sőt szükségszerü az Ég alatt, ahogy távolságuk is az emberektől, tünékenységük is az. Az utóbbi esetében pedig a dao értékmérőjévé válik az „alantas írástudók” róla szóló véleménye, amelynek korlátoltsága a mutatója: „Ha [...] [alantas írástudó] (xiashi) hall a daoról, nagyot nevet rajta. Ha nem nevetne rajta, (az, amiről hallott) meg sem érdemelné, hogy daonak nevezzék" (Laozi XLI, Tőkei 2005, II: 31).

Megjegyzendő azonban, hogy épp a „kiismerhetetlenség” mint a „legjobbak” e becsült tulajdonsága (vagy ennek kívánalma) - ha fogalmi bevezetése helyén (Laozi XV, Tőkei 2005, II: 21) az „egyszerüség” erényével együtt használatos is, azzal egyként elismert - a jelen passzus első felében megfogalmazott „egyszerüség-tétel” viszonylatában, miszerint: „Az én szavaimat nagyon könnyü megérteni, s nagyon könnyü megvalósítani is őket” (Laozi LXX, Tőkei 2005, II: 41), mégis ellentmondásosnak hathat. 
várnánk is -, miszerint „minden ember (boxing 百姓) szalmakutya (chugou 㫚狗)" "53. Épp ellenkezőleg, - ahogy már láttuk - Laozi erényét, „értékét” köti az ilyen megkülönböztetéshez: ezáltal is kiemelve annak fontosságát, szerepét - csökkentve a „titokzatos azonosítás” mértékét. ${ }^{54}$

\section{Az uralkodó mint shengren}

A XXXII. fejezet szerint a dao erényét Laozi a „fejedelmek és királyok” (houwang 侯王) kompetenciakörébe utalja és ajánlja; meghagyva, hogy amennyiben „képesek rá, hogy megőrizzék”, teljesül a rend legmagasabb szintü megvalósulása: a magától való beteljesülés, mely nem kívánja a parancsszót, mégis a legteljesebb harmóniát hozza el - fejedelmek és királyok becsületére. ${ }^{55}$ A daót és az úton járó „tízezer lényre” (wanwu) tett hatását ${ }^{56}$ a houwang kompetenciájába vont és - a konfucianizmussal rokon módon megnyilvánuló ${ }^{57}$ - közvetítettség kérdése jellemzi tehát, ahol az uralkodó(k) erénye (de) - kisugárzásában - képes az égalattit és annak minden lakóját (egyszeriben) erényessé tenni.

A XXXVII. fejezetben foglaltak rímelnek az előbbiben megfogalmazottakra - bizonyos helyeken szóról szóra elismételve ezeket - azzal a kiegészítéssel megtoldva, hogy amennyiben a wanwu „megváltozván is tevékenykedni akarna”, a szerző - magamaga - „megfékezné a névtelen egyszerüségével" ${ }^{158}$. A ,névtelen egyszerüsége” (wuming zhi pu) vágymentesség (buyu), a vágymentesség nyugalom: nyugalom a belsőben és a közösségben egyaránt. ${ }^{59} \mathrm{~A}$ fejezet tanúsága szerint tehát a Laozi szerzője a „daóba helyezkedett” (vagyis

53 Laozi V, Tőkei 2005, II: 18: „Az ég és a föld nem emberséges (ren), minden létezővel (wanwu) úgy bánik, mint afféle szalmakutyával. A bölcs ember sem emberséges, úgy bánik az emberekkel (boxing), mint afféle szalmakutyákkal."

54 A „titokzatos azonosítás” gyakorlata (lásd 42. lábjegyzet) mint a shengren erénye a jelen fejezet közlésétől sem idegen azonban, kiváltképp, mikor a „bölcs ember” pórias, egyszerü megjelenését írja le - akárha metaforikusan is - és dicséri, mint amely a fénylőt takarja.

55 Lásd 25. lábjegyzet és kapcsolt föszövegbeli tartalom.

56 Vö. Chen 1989: 37.

57 Lásd újra 25. lábjegyzet.

58 Laozi XXXVII, Tőkei 2005, II: 29. A „névtelen” taoista koncepciója kapcsán vö. Hansen 1992: 218 és Várnai 2013: 396.

59 Lásd 24. lábjegyzet és kapcsolt föszövegbeli tartalom. 
ő maga shengren), mi több, egyfajta kormányzati pozícióban találunk rá - ha ez a pozíció akár csak remélt is.

A nép, azaz az „alattvalók” (xia 下) és a „legfelsőbbek” (taishang 太上) elitárius megkülönböztetésével és egymással való szembeállításával találkozunk a XVII. passzusban is: lenyomataként tehát annak, hogy - akárha a vágyott uralkodó „meggondoltságával minden szavának megbecsülést [is] szerez" és viszonya harmonikus a néppe ${ }^{60}$ - Laozi differenciált társadalmihatalmi viszonyokban kénytelen gondolkodni az elemző leírások során, ahol egyértelmü és határozott politikai állásfoglalásban nyilvánul meg ezzel egy időben. A „nép bizalmának elvesztését” (buxin 不信) megelőzendő hatalomgyakorlat ${ }^{61}$ vázlata ugyanis - melyet itt kínál - az uralkodói kontroll fokozódásának elítéléséből adódik, hiszen a kezdeti idilli állapottal („A legfelsőbbekről az alattvalók éppen csak tudták, hogy vannak ${ }^{\text {"62 }}$ ) egyértelmüen konfrontált a későbbi/akkori, ahol is a vezetés - tanítja az „Öreg mester” - konkrét társadalmi repressziót fejt ki.

Ugyanígy - „mert »határainkon belül« négy nagyság létezik, s a király (wang) ezek közül az egyik megtisztelő helyen lakozik"63 - a wang nagyságát, kitüntetettségét hangsúlyozva Laozi a XXV. fejezetben is hitet tesz az uralkodói státusz és hatalom daoerényes fenntartásának szükségessége mellett, mégpedig annak kozmikus, világfenntartó jelentése, jelentősége miatt.

Az LIV. fejezet hangsúlyos, szuggesztív megfogalmazása szerint pedig: a dao ereje, a tanítás követése biztosítja az azt beteljesítő számára a remélt megmaradást és az erénybeli gazdagságot a társadalom minden szegmensében (hiszen a társadalom legbenső mivoltát is maga a dao adja ${ }^{64}$ ), illetve általában véve is (pl. ,akit jól átölelt [a dao], azt nem lehet elmozdítani”" ${ }^{65}$ : ennek politikai irányultsága továbbá már a fejezet elején erős alaphangadó). Az „el-

60 Laozi XVII, Tőkei 2005, II: 22.

61 A Daodejing elött már a konfuciánus tanítás is kiemelten kezeli e hagyományos problematikát: a „nép bizalmának elvesztését” főbenjáró vétekként ítéli el, mely vétek az Ég haragját vonja magára, és az uralkodó letaszíttatik (geming 革命) (vö. Lunyu XII.7, Tökei 2005, I: 115: „... ha a nép nem bízik benned [aki uralkodsz felette], nem állhat fenn [az uralmad]”, illetve Mengzi VIIB: 14, Tökei 2005, I: 326: „A nép a legfontosabb, a föld- és gabonaistenek csak másodsorban következnek, $\mathrm{s}$ a fejedelem a legkevésbé fontos" stb.).

Laozi XVII, Tökei 2005, II: 22.

Laozi XXV, Tökei 2005, II: 25.

64 Vasziljev 1977: 189.

65 Laozi LIV, Tőkei 2005, II: 35. 
mozdítani” (tuo 脫) kifejezés használatával a szerző a politikai-közéleti jelenlét több szintjét is képes volt lefedni, már ami a shengren (politikai) karakterét illeti: mindenekelött azonban a bölcs(-király) alapvető erényének megfelelő - annak „mindent megtenni képes” - „mozdulatlanságára”66 utal. A hatalmipolitikai utalás egyértelmüségét a továbbiakban - legelőször is az idézett sor után következőben - kifejtettek mutatják: az „ősök erényének” megmaradását, hatalmi pozíciók továbbörökítését és megöröklését a „fiak és unokák” (taoista) áldozattételéhez köti a szöveg.

A passzus kifejtö részében egy hierarchikus egészre vonatkozó, részletekbe menő leírást találunk, mely leírás egy, általános érvényre hozott direktívát tartalmaz (,tégy rendet [xiu 修] mindenütt!”); amelynek követése következményeképp a hierarchia minden szintje az égalattival bezárólag felvirágzik, erényében prosperál, kiteljesedik. ${ }^{67}$ Bár a Laozi esetében - és ezt fontos hangsúlyozni - a hierarchia kevéssé vagy talán egyáltalán nem jelent hivatali ranglétrát, hivatali pozíciót, hanem többnyire természetes módon létrejött szerveződések egy rendszerét jelenti, illetve e szervezetek vezetőinek egymáshoz való viszonyát (itt: saját magunk - a családfö - a falu vezetője - a fejedelem - az Ég Fia), kétségtelenül összefonódik a taoista erény, a xiu taoista feladata egy hierarchikus fokozatossággal, e szervezetek vezetőinek szolgálatával.

Alkalmazva a laozi-i tételt, miszerint: amit a daóval illetnek, amihez a daóval közelítenek, az egyszerüségében megjelenik elöttünk, ${ }^{68}$ megérthetjük, miért áll fenn kapcsolat a daónak megfelelő „kiteljesítés” és önmagunk, a család, a falu stb. „megismerése” között. Hogy ezekről megismerjük, mik is önmagukban, egyszerüségükben, természetességükben, szükséges a taoista, minden megerőszakolástól mentes lényeglátás, a hatalmaskodó rendszerek okozta torzítás alóli felszabadítás, melyet követően válik lehetővé a felismerés: mi az, ami egyszerü létünkben mi vagyunk; milyen a család és a falu, ha nem éri

66 Lásd 29. lábjegyzet.

67 Vö. ezzel szoros párhuzamban A nagy tanitás (Daxue), Tökei 2005, I: 185-186: „A régiek, amikor világossá akarták tenni a fényes erényt az egész égalattiban, először rendet teremtettek (zhi) a fejedelemségükben (guo 國). Amikor rendet akartak teremteni a fejedelemségükben, elöször rendbe tették ( $q i$ 齊) a családjuk (jia 家) ügyeit. Rendbe akarván tenni a családjuk ügyeit, elöször tökéletesítették (xiu) saját magukat (shen 身). [...] Ha tökéletesítettük magunkat, akkor rend lesz a családunkban. Ha rend lesz a családunkban...” stb. Továbbá vö. Lunyu XIV.45, Tőkei 2005, I: 134: „,A nemes ember] úgy tökéletesíti (xiu) önmagát (ji 己), hogy nyugalmat tudjon biztosítani az egész népnek (boxing), bár ez még Yaonak 堯 és Shunnak is nyugtalanságra adott okot.”

Laozi XXXIX, Tökei 2005, II: 30-31. 
káros represszió; milyen egy fejedelemség, ha esztelen erő helyett a daóval kormányozzák; milyen az égalatti, ha egy bölcs király erénye alatt egyesül.

Az az állítás, miszerint a szerző - saját bevallása szerint - az égalatti ,ismerője", mégpedig annak ismeretét saját magának az ismeretéhez köti, feltételezni látszik, hogy önmaga erényét a bölcs király erényéhez, az Ég Fia szentségéhez közelíti, valójában megfelelteti annak. Hagyományosan ugyanis az égalatti ismerete az ,égi jelek megértésének” következménye, azok égalatti leképezése: ennek erénye pedig egy az egyetlen király erényével; az egyetlen király pedig egy az égalattival. ${ }^{69}$ Ez a konklúzió persze korántsem hat idegenül a korpusz egyéb részeinek vonatkozásában, hiszen a taoista erény megtestesítője - akár a szerző az, akár egy ideál - legtöbbször maga a bölcs király képét ölti fel a tanításban, erényét azzal egyezteti. Épp ezért érdekes a jelen passzus hangsúlya, miszerint a daónak való megfelelés mindenki feladatában áll: erősebb értelemben ténylegesen, gyengébb értelemben - amelyet támogatunk - a bármiféle hatalommal, akár nem politikai hatalommal bírók körén értelmezve. Még e gyengébb értelem mellett is azonban világosan látszik a tetemes különbség a csupán a legfőbb vezető (esetleg vezetők) erényének mintául szolgáló tanítás és a „sokaság embereit” (zhong 衆) megszólító mintaadás között azok konzekvenciáit tekintve. Hogy ezek jellegében, lényegükben valójában még sincs különbség, érthetjük: a taoista király paradoxonja épphogy feloldódni látszik a ,mindenki teljesítse ki magát” (jie [...] xiu shen 皆 [...] 修身) - konfuciánus ihletettségü ${ }^{70}$ - taoista tételében, amikor is a hierarchia vagy a köz emberét taoista „tétlenségre”, a taoista tanok beteljesítésére szólítja fel Laozi. Megjegyzendő azonban, hogy a király erénye még ekkor is megkülönböztetett marad: ,aki pedig [...] [rendbe teszi az égalattit], annak erénye [...] [teljes] ( $p u$ 普) lesz". ${ }^{71}$

Továbbra is: „Aki a fejedelemséget birtokolván az Anyához megy, maradandóságot biztosít. Ezt nevezik mély gyökérnek és biztos alapnak. Ez [...] [a tartósan jelenlévő] dao". ${ }^{72}$ Az LIX. fejezet értelmében tehát az erényes fejedelem a ,daóba helyezkedik”, azt ,minden dolog”, így hatalma alapjának tartva, a „legyőzhetetlent” és „határtalant” hívja segítségül, mely(ek) ereje, hatása

${ }^{69}$ Vö. Laozi XIII, Tökei 2005, II: 21: ,az égalattit csak arra lehet rábízni, aki úgy előkelő [feljebbvaló] (gui 貴) [...], hogy saját énje egy az égalattival”.

70 Daxue, Tőkei 2005, I: 186: „Az Ég Fiától kezdve egészen a köznépig (shuren 庶人) minden egyes ember számára önmagának tökéletesítése a legfontosabb (ben 本).”

71 Laozi LIV, Tőkei 2005, II: 35.

72 Laozi LIX, Tőkei 2005, II: 37. 
(de) révén biztosan és maradandón a maga - s így a dao - „,birtokában” tudhatja a fejedelemséget.

Felütésében aztán a LX. fejezet is csatlakozik az azt megelőzők sorába, mikor is a „nagy fejedelemség kormányzását” bagatellizálja - a dao követését írva elő egyetlen feladatként. A továbbiakban azonban nem várt következtetéseknek lehetünk itt tanúi: Laozi jóslata a „gui 鬼 szellemek" kártékony praktikáinak elmaradásáról - amelynek érvényét az előbbi feltétel megvalósulásához köti - már jelzi az érvelés eltérő irányát (amennyiben valóban a vallásos tanokat ekképp felhasználó szerzői megnyilatkozásról van szó, és nem - ennek álcája mögött - a régi tétel ismétléséről, miszerint „,élő” és ,holt” csupán ugyanannak az éremnek két oldalát jelentik ${ }^{73}$ : s ezt felismerve a „,csodák” elmaradnak). A daokormányzás megkülönböztetett erényét hangsú-

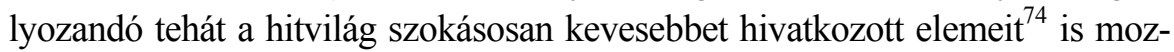
gósítja Laozi, mikor is a holtak hazajáró szellemeinek e kormányzást követő, feltehető elégedettségéről és békéjéről nyilatkozik. E szellemek ugyanis - hagyományosan - az elmaradó áldozatok utáni sóvárgásukban válhattak veszélyessé, zavart keltővé, ${ }^{75}$ így jövendölt nyugalmuk, ,ártó csodáik” féken tartása

73 A kínai „túlvilág” evilági - legkevésbé sem transzcendens. Ezért „élő” és „holt” megkülönböztetésének ilyen feloldása amúgy nem áll szemben a vallásos tanokkal.

74 Tőkei a Daodejing Weöres Sándor-féle fordításához írt jegyzeteiben e szellemeket, illetve ezek fogalmát a „holtak szellemei” formában mintegy azonosítja az „ősök” fogalmával; érvelése során legalábbis a leghatározottabban közelíti ezeket egymáshoz, mikor is az utóbbival nevezettek hitvilágban (és a tényleges kormányzásban) betöltött szerepét, jelentőségét ruházza az előbbiekre (Weöres 2001: 106: „Míg az úton járnak az emberek, nem müvelnek csodát a szellemek - azt jelenti: ha a kormányzás minden dolga a dao szerint való, akkor a holtak szellemeinek semmi szerepük nem marad. Ez éles támadás a konfucianizmus ősök-kultusza ellen."). Valójában azonban a kínai hitvilágban szokásosan a „gui szellemek” néven hivatkozott (élő-)holt lélektestek státusza, rangja nem érte el a - tulajdonképpeni - „ősökként” tiszteltekét, azok erényétől, hatásától esetenként lényegileg, máskor mérték tekintetében elmaradt. Hiszen e fogalomkört alkalmazva vagy a (nemesi) holttesttel a sírban maradó és áldozataitól megfosztottan kószálni indult, kártékony szellemekre utaltak (Maspero 1978: 153), amelyek - lévén a holttest enyészete, egyben a gyászidő lezárulta saját végüket is jelentette (Maspero 1978: 154) - nem emelkedhettek az „ős” rangjára (ugyanis „,a nemrég elhunyt csak a gyászidőt befejező áldozat után vált őssé” Maspero 1978: 158); vagy azokra a „tömeggé degradált ősökre", akik a nemzedékek egymást követő sorában egyre távolabb kerülve áldozó utódjuktól többé nem kaptak már személyüknek szóló áldozatokat (Maspero 1978: 159), s így erejük lehanyatlott, erényük személyessége megszünt, feloldódott egy általánosban. Ekképp tehát a ,gui lelkeknek” az, „ősöktől” való megkülönböztetése indokolt és - a fentebbieket alátámasztandó - igényelt is.

75 Maspero 1978: 153. 
- a szerző szándékai szerint - egy (számukra is) kívánatos és erényes (ha nem a legerényesebb) kormányzat dicséretévé válna. Akárcsak a shengren nyugton maradása - ahogy Laozi tanítja újra csak és ugyancsak először e meghökkentő formában: hogy a ,gui szellemek" megbékéltek, s ,,az égalattit a daoval kormányozzák, [...] a bölcs ember (shengren) sem árt többé az embereknek" "76.

A kártékonyság, minden tett-ártalom mellözése mint erény, mint kötelesség a Laozi lapjain szinte mindig a bölccsé lett uralkodó-kormányzó figurájához, annak fogalmához kötötten jelenik meg: hogy ez esetben a „,shengren” válik e reguláció tárgyává (és alanyává), - bár zavarba ejtő lehet számunkra a neki immáron felrótt eddigi, ártó kellemetlenkedés - világosan mutatja e két fogalom egyezősségét, uralkodóét és shengrenét. Az iménti zavar is könynyen feloldást nyerhet azonban, ha belátjuk: a magyarázat során alkalmazandó taoista tétel, miszerint „előbbi és későbbi egymást követi”, 77 konzekvenciáiban megengedi, sőt támogatja az efféle, esetlegesen fennálló, ámde regulatív, időbeli és/vagy logikai megkülönböztetettség, mint az uralkodó és shengren fogalmi kettősségének aktuális érvénytelenítését. Minthogy uralkodóból shengren, shengrenből uralkodó válik - ahogy láttuk (és látni fogjuk még): kettejük erénye, akárcsak kártételük tehát egy (lehet), és mert e minőségeik határozzák meg fogalmukat, maguk is egyek (vagy egyek lehetnek - az ennek megfelelő laozi-i álláspontra helyezkedve). A megtévesztő - mondhatnánk újra: paradox - kifejezéshasználat ${ }^{78}$ ellenére is világos azonban a szerzői közlés a továbbiakat tekintve (is): a bölcs elöljáró az ártatlan ,gui szellemek" méltó párjaként maga is ,üres szellemmé” lesz, de-je azokéval - ahogy Laozi írja - „találkozik és egyesül”" ${ }^{79}$ Ez a közös jelleg, mely esetükben a daónak leginkább megfelelő, erényük (közel egyedüli) meghatározója: „,nem ártani”, „elmaradni”.

A LXV. fejezet tanítása szerint a „nem-tudás segítségével kormányozni” (bu yi zhi zhi 不以智治) a dao szentjeinek egy (kizárólagos) eszköze, hogy a fejedelemséget boldog egyszerüségében tudhassák, és így annak prosperitását biztosíthassák. Ellenben a nép ismereteinek gyarapításával, amely ál-

\footnotetext{
Laozi LX, Tökei 2005, II: 37-38.

Laozi II, Tökei 2005, II: 17.

78 Szemben az eredeti kifejezést (,,shengren”) hűen tükröző Tőkei-féle fordítással (,,bölcs ember”), Weöres verses tolmácsolásában értelmező fordítását adja a terminusnak („fejedelem"), így csökkentve a felmerülő értelmezésbeli nehézségeket (Weöres 2001: 76). A terminusértelmezések paradoxonjellegéröl lásd Wu 1995: 37. Laozi LX, Tőkei 2005, II: 37-38.
}

79 
lhatatosságot, irányításbeli nehézségeket szül, és e zavarnak a guojia 國家 (,az ország és családjai”) látja kárát - hangzik Laozi taoista érve. S ha eközben a „régi időkre” utal is, világosan látszik, hogy a fejedelemség - egyedül megbízható - vezetését azok kompetenciakörébe vonja, akik ,[tudják], hogyan kell gyakorolni a daot" ${ }^{\prime 80}$. A taoista kormányzás ilyen alapvetését megérteni egyébként illetékességet jelent „mérték és példa” dolgában - állítja a szerzo; továbbá frappáns választ kapunk még az esetenként egymásnak és általában a mindennapi ítéleteinknek ellentmondó taoista tételek paradoxiája ügyében is.

Az első állítást tekintve meg kell jegyeznünk, hogy „,mérték és példa” ismeretének feltevése határozott tagadásává válik a mủ minden, relativizmussal áthatott gondolatának - holott e gondolatok tendenciája az, mely a Daodejing közel egyetlen, konzekvensnek tűnő vezérmotívuma lehetne. És mégsem: a minden repressziónélküliséget hirdető „bölcs ember” mintaadásában maga válik (ennek is) korlátozó tényezőjévé - és szükségképpen. Ezért e nagyszerü - és paradox - kellés: „Ha müvedet véghezvitted, nyomban vonulj vissza, (mert) ez az ég daoja." $" 81$

A másik kérdés pedig, melyben a laozi-i tételek paradoxonteremtésének egy magyarázatát nyerjük, a „titokzatos $d e$ ” jellemzőinek vizsgálatához utal minket: kiindulópontját - az eddigiek értelmében - „mérték és példa” ismeretében, használatában állapítja meg a szöveg, hatását sokszorosnak tartja. Állítja, „vele lehet eljutni a nagy összhanghoz (dashun 大順)”, úgy mégis - és most számunkra ez a fontos -, hogy a de:,,a dolgok átfordulása" (wufan 物反). ${ }^{82}$ Ha a „titokzatos $d e$ " müködése során - látjuk - irracionálisan hat, a ,nagy rendezettséget" mégis ennek köszönhetjük, szabálytalanságával megtéveszti a szemlélőt: a megtévesztettség leírására és a szemlélet kitágitására pedig mi más lenne a legalkalmasabb eszköz, mint a paradoxon?

\section{A shengren mint uralkodó}

„A Daodejingben a Bölcs alakja egy szent uralkodó formáját ölti, egyfajta demiurgoszét, a dao antropomorfizált képviselőjét" ${ }^{\$ 3}$ - fogalmaz Isabelle Robinet A taoizmus kialakulása és fejlödése címü könyvében. S valóban, amint a Laozi

\footnotetext{
${ }^{80}$ Laozi LXV, Tökei 2005, II: 40.

81 Laozi IX, Tökei 2005, II: 19.

82 Laozi LXV, Tőkei 2005, II: 40. Vö. Laozi XL, Tőkei 2005, II: 31: „Az [...] [átfordulás] (fan): a dao mozgása".

83 Robinet 2006: 56.
} 
XLVII. fejezetében is, a szent király archaikus-ideáltipikus jellemzői a „bölcs ember" taoista-ideáltipikus jellemzőiként - mint sematizmus - állnak elöttünk. A „mozdulatlanságában” messzeható királyi erényhatalom valami teljessége fogalmazódik meg abban a leírásban, amely a bölcset - karizmája révén mintegy (királyi) origópontba állítja és utalja: egy helyben maradása, tevékenységének egyfajta szakrális korlátozása, a megismerés és megnevezés karizmatikus, szent gyakorlata mind-mind kifejezi világfenntartó szerepének ősikirályi jellegét. ${ }^{84}$

Mintha folytatásként, a „bölcs ember” XLIX. fejezetbeli jellemzésekor Laozi - láthatóan - következetessé, egyben plasztikussá kívánja tenni e („sarkcsillag módjára”) „mozdulatlanul” erényt tevő uralkodó képét, amikor a szövegrész felütésében (a shengren „a nép [boxing] szívét teszi saját szívévé" ${ }^{85}$ ) először is (újra) egyértelmüsíti, hogy bölcsét a királyi erény birtokosának: az égalatti vezetöjének tartja; később kifejti, hogy e vezető érzékelésében, ténykedésében „csecsemőhöz” (hai 孩) hasonlatos, kinek egy helyben maradása, elemi világlátása és reakciókészsége a „mozdulatlanul” is erővel ható királyi erény jellemző formája (lehet). „Félénkség”, ,egy-ügyüség”, „,csecsemőlét” stb. mind-mind olyan tulajdonság, mely igencsak távol áll a konfuciuszi hagyományban megfogalmazódó „mozdulatlan uralkodó” habitusától; mégis (vagy épp ezért) képes e leírás az Ég Fia uralkodói karakterét annak archetipikus eredetijéhez közelíteni: a szakralitás ideális megtestesítője igenis „Árva”, „Elhagyatott”, „Ellátatlan” lehetett, ${ }^{86}$ erényében megkülönböztetett, elkülönültségében egyedülálló.

Ha elfogadjuk Tőkei értelmezését - melyet a szövegösszefüggések is alátámasztanak -, miszerint Laozi itt ismét nyilatkozatot tesz saját shengrenségéről

84 A hivatkozás archaizmusairól, az Ég Fiának hagyományos-szabályos erényeiről, kötelességeiről és az ezeknek megfelelő elvárásrend szerinti életéről lásd Maspero 1978: 128-136. Továbbá párhuzamosságok megállapításához és az ideáltipikus vezető erénytanához vö. a Lunyu releváns passzusaival, elsők közt is a már idézett II/1.-vel (lásd 29. lábjegyzet), illetve a Csatolt magyarázatok 1. pontjában foglaltakkal (Yijing: Xici 1, Tökei 2005, I: 47: „Aki [...] megragadta az égalatti törvényeit, az székhelyet állít magának a középben").

Laozi XLIX, Tökei 2005, II: 33.

86 Laozi XXXIX, Tőkei 2005, II: 30-31: „S ezért mondják önmagukról a fejedelmek és királyok: »Árva«, »Elhagyatott«, »Ellátatlan«. Nem azt jelenti-e ez, hogy a jelentéktelent tekintik alapnak?”; Laozi XLII, Tőkei 2005, II: 32: „Amitől az emberek legjobban irtóznak, az éppen az »Árva«, »Elhagyatott«, »Ellátatlan« állapot, s a királyok és fejedelmek (wanghou) mégis így nevezik magukat." 
(,Én <a bölcs>" ${ }^{\text {87 }}$ ), azt is érvényesnek kell elfogadnunk, hogy ő az (ő legalábbis mindenképp), aki ,a nép szívét teszi saját szívévé”. Azét a népét, amely „ragyog”, „fürkész” és „,kutat”, ${ }^{88}$ vagy - ahogy itt fogalmaz - „megfeszítve figyel szemével és fülével" ${ }^{\prime 89}$ : felmerül a kérdés, az uralkodó bölcs hogyan gyakorolja erényét a nép felett, ha annak szellemét magáévá teszi. Egy, már megelőlegezett válasz szerint ${ }^{90}$ - amelynek épp a passzus jelen tétele szolgál alapjául - a bölcs, amikor „a jókkal jól bánik”, s ugyanígy a „rosszakkal”, „egy-ügyüségében”, differenciálatlan ítéletében (amely a „minden ember szalmakutya" tételben is - bizonyos formában - megfogalmazódott) harmóniát teremt az égalattiban, vagy - helyesebben szólva - az égalatti eredeti harmóniáját tételezi.

A taoista kormányzástan alapvetését, első és végső iránymutatását, metodikai origópontját tartalmazza az LVII. fejezet, és nyilatkozik újra erről - bizonyos fordulatokat felfrissítve, de lényegét-egészét tekintve változatlanul elöadva: a „bölcs ember” kormányzása tehát - ha az égalattit „meghódítani” (ebben az esetben leginkább csak: „megnyerni”) kívánja és persze nem a maga javára - a kormányzás, a hatalmi manőverek berekesztése. A tett-kormányzás, az „ügybuzgalom” (shi) felszámolása, így a nép, az égalatti üdve egyedül a bölcs erényén múlik: visszavonulásával a hierarchia, a hatalmi felépítmény egésze szünik meg egy csapásra - megszünik a népre nehezedő teherként annak önmagát legelemibb, egyben legteljesebb módon fenntartani képes életerejét csapolni. A bölcs uralkodó vágyak, hatalmi törekvések és egyáltalán bármi, szolgálatokat, szolgálattételt követelö tett nélkül (wuwei) biztosítja népe nyugodt és gazdag életét; azt, hogy az lehessen, ami: „faragatlan fa”. Az elemi következtetés, a „magától való beteljesülés” gondolatának határozottsága pedig ezen a ponton is erősíti a „bölcs ember” „kitüntetettségét”, hatását, de-jét. ${ }^{91}$

Egy, a hatalmi tétlenség üdvözítő hatásának tételét alátámasztani hivatott érvkísérlet(-sor) uralja a fejezet első felét, mely szerint: a nép nyomora és láza hatalmi érdekek és úri kiváltságok mentén mérhetö. A fegyverek vívhatnak háborút az uralkodó „dicsőségére”, és ugyanúgy lehetnek vesztére is, ha lázadnak ellene; a kiváltságok és ritka tárgyak birtoklása megosztja az embereket, és ellenségeskedést szül, ezért forrásuk és mesterük nem kívánatos; a törvény-

\footnotetext{
Laozi XLIX, Tőkei 2005, II: 33.

88 Laozi XX, Tőkei 2005, II: 23.

89 Laozi XLIX, Tőkei 2005, II: 34.

90 Lásd 41. lábjegyzet és kapcsolt föszövegbeli tartalom.

91 Vö. Liu 2009: 231-232.
} 
kezés és bíráskodás pedig csak kriminalizál, rablókat és tolvajokat szül - amint Laozi mondja. ${ }^{92}$ Ezzel minden hatalmi apparátus tevékenységét kritizálja - ahogy tette ezt már sokszor ${ }^{93}$-, következtetését pedig az előbbiek értelmében levonta.

Az LVIII. passzus követi és részben megismétli az előzőekben foglaltakat: a kormányzat tétlenségére szólít fel, hogy a nép „egyszerü és boldog” lehessen. Érvét azonban ezen a ponton fogalmazza meg a legáltalánosabb érvénnyel (amennyire csak lehetősége van erre): igaz és hamis, jó és rossz végső, valódi megkülönböztetésének kritikájával a „bölcs ember”, és amit hozzá köt, a kormányzat erényét abban határozza meg, hogy különbségtevés híján nem vállalnak beavatkozást senki életébe, ezáltal biztosítva a nép nyugodt megélhetését, amelyet természetes életvitele tart fenn. Kiegészíti még ezt azzal, hogy míg a shengren erényénél fogva valamiféle kitüntetettséget élvez, mások ennek híján nem szenvedhetnek kárt: a bölcset e kitüntetettsége nem hatalmazza fel mások regulálására, erőltetett „rendbetételére”.

E kiegészités megtétele előtt is érezhető feszültség a passzus koherenciáját tekintve, mikor is Laozi igaz és hamis összemosásával - nem is leplezett módon - relativizálja a nép számára „szerencsésnek” ( $f u$ 福), illetve „szerencsétlennek" (huo 禍) tartott kormányzás közti különbséget. A kiegészítéssel megjelenő fordulat azonban - ha nem lennénk már jó elöre felkészítve minden lehetséges paradoxonra - egészen meghökkentő lehet, hiszen a minden érvényességet megkövetelő relativitástétel konzekvenciáival szemben itt mégis „bölcs ember” és közember különbségéről, előbbi paradox felsőbbségéről ad számot Laozi, miközben épp ennek de-jéről, a megkülönböztetésnélküliségből fakadó be nem avatkozás erényéről nyilatkozik. És mégis, épp ez utóbbi erény megfogalmazásával (miszerint „nem nyeseget [másokat]”, ${ }^{94}$ stb.) eltávolítja Laozi „bölcs emberének” e fejezetben kialakított képét a más fejezetekben, elsősorban a XXVII.-ben körvonalazottól, ahol a bölcset ,jó embernek” (shanren 善人), a közembert, a „gondjaira valót” „nem-jónak” (bushanren 不善人) nevezi, és ez utóbbit művelésre, ,gondozásra” ( $z i$ 資)

92 Lásd részben 19. lábjegyzet.

93 Lásd sok más mellett Laozi LXXV, Tőkei 2005, II: 43. A nép és az elit közti viszony problematikájának részeként a szerző itt is kritika alá vonja és felelőssé teszi a vezetést a nép nyomorúságának előidézéséért és fenntartásáért - $\mathrm{s}$ teszi ezt mind élesebben. Az uralkodó réteg élősdi mohóságát és mindig kész, haszontalan tetterejét vádolja Laozi az emberek kifosztásában és felesleges gyötrésében, tanítva a régit: kormányozni a népet úgy lehet könnyen és jól, ha kevesebbet kormányozzák.

Laozi LVIII, Tökei 2005, II: 37. 
szorulónak tartja ${ }^{95}$ - jelezve ezzel kettejük különbségének valós hatalmi aspektusát.

A LXVI. passzusban - mindezek után és hangsúlyosan - kényszerítö erejü természeti hasonlattal érvel Laozi a shengrennek - a wang tisztében való önzetlen szolgálatkészsége, a népnek való alárendeltsége, illetve ezeknek szükségessége mellett; annak érdekében, hogy bölcs irányítását elfogadja és tartósítsa az égalatti. Önmérsékletre szólít tehát Laozi a vezetésben, a „bölcs embert" kitüntetettségében: mert az égalatti kormányzója, aki erénye révén képes e feladatát maradéktalanul ellátni, nem más - látjuk -, mint a „daóba helyezkedett", a shengren. Hogy népe számára ne jelenthessen terhet vagy gondot e bölcs uralkodó, mégis „felül álljon” (shang 上), s ,elöl” (xian 先), de-je müködtesse az égalattit, korlátoznia kell magát retorikájában és céljai megvalósításakor - szól az intelem ${ }^{96}$-: háttérbe kell húzódnia, így előtérbe kerül erénye. A szöveg cserébe tartósan fennálló hatalmat ígér: ezáltal is mindinkább kívánatossá téve a taoista kormányzás elveinek elfogadását, megtartását - mint a politikai és erénytani zürzavarral szembeni fellépés stratégiai szuggesztióit. ${ }^{97}$

Mindezt követően bizonyos feszültséget kell éreznünk azonban - mely visszatérö -, hisz más szöveghelyek tanúsága szerint, ${ }^{98}$ láthatjuk, a tartós vezetés ígéretével egyértelmüen szemben áll a „bölcs ember” szükségszerü és mielőbbi visszavonulásának kényszere. Hogy az egymásnak ellentmondó paszszusok e dominanciaharcából egyáltalán kikerülhet-e valamelyik „győztesen”, aligha hihetjük, ${ }^{99}$ mégis bizonyos preferenciák megfogalmazásának alapjául szolgálhatnak a szöveg egyes súlypontjai mint kiindulópontok. Lényegre törő fogalmazásmód, határozott állásfoglalás, érvelési potenciál: ezek egy adott szövegrészletet jellemző, koncentrált jelenléte mutathatja fel a mondanivaló kitüntetettségét. Minthogy e jellemzők egyként erősségei e passzusnak (is),

95 Laozi XXVII, Tőkei 2005, II: 26.

96 Lásd továbbá Laozi LXI, LXXVI, Tőkei 2005, II: 38, 43.

97 Chan 2000: 18.

98 Pl. Laozi IX, Tőkei 2005, II: 19.

99 A manapság is népszerü, miszticizáló, tekintélyelvű hagyomány inkább még szemben áll egy ilyen igénnyel, mondván, a mü egyes részeinek - és azok egymáshoz való viszonyának - megértését a mủ teljességének egy adekvát - leginkább egységes egészként való - megértése teszi lehetővé, és csakis ez. Egy ilyen értelmezési hagyomány egyébként - minden torzító vonása ellenére - könnyen számot tarthat az elismerésre, hiszen a jelentéstani tér egységesítésével, mely első teljesítménye, hủen tükrözi a Laozi daoszellemiségét. 
mondhatjuk, mint ilyen tartalmi ,gócpontnak”, megállapításainak, indítványainak megkülönböztetett szerep juthat az interpretáció során. Ennek értelmében tehát a „bölcs ember” politikai elsőségére tett jelen utalások, annak elérését, megtartását célzó metodikai utasítások igen nagy súllyal esnek latba, ha a szövegösszefüggések ingatag talaján vizsgálódunk - annak ellenére, hogy ezek megfogalmazásában a laozi-i felfogástól egyébként oly távoli célelvüség is tükröződik: „Így tehát (a bölcs embernek), ha fölötte akar állni a népnek, akkor úgy kell beszélnie, mint aki alatta áll"100 stb.

A LXVII. fejezet mintegy az előző folytatásaként továbbviszi azt a gondolatot, miszerint csakis az lehet „feladatát jól betöltő vezető”, aki önmagát háttérbe szorítva népének kedvez csupán, s hogy egyéni vágyait mérsékli, hatalmaskodni pedig nem merészel ő, valóban „hatalmassá” (guang 廣) lehet. A politikai közéletben való közlekedés során általánosságban - de kiváltképp az uralkodó magatartásában - alkalmazandó, az előzőekben már megalapozott, itt pedig explicitté tett „hármas parancs” tételének be nem tartásával azonban - és ez hozza az első (egyben legfontosabb) újdonságot a megelőző passzushoz képest -, a hatalomra törő vagy azt birtokló saját ,pusztulását” ( $s i$ 死) idézi elő - miként Laozi fogalmaz. A „kincsek” (bao 寶) - ahogy a szerző e kötelmeket és követendő magatartási mintákat nevezi - a ,gondoskodás” (ci), melynek gyakorlásával lehetünk csak egyedül biztonságban, ha „,bátorságra” van szükség a hadviselésben vagy másutt; a „mérséklet” (jian 儉), mely egyedüliként képes „,hatalmassá” tenni; és a törtetés elítélése, „önmagunk háttérbe helyezése” (hou 後), mely a jó kormányzáshoz vezető egyedüli út - összegez ekképpen a szöveg.

Hogy ezek a „kincsek” a szerző birtokában (is) vannak, tájékoztat róla az írás, és hogy gyakorolja erényüket, az előbbiek értelmében ehhez sem férhet kétség; ennek azonban (el)várt következményei, a - hihetnénk - megvalósult szent kormányzásban való legmagasabb szintü részvétel ${ }^{101}$ kapcsán aligha találunk utalást e passzus sorai közt. Inkább kiolvasható azokból egyfajta személyes felkészültség, vélt alkalmasság, mely az égalatti kormányzását illeti - szembeállítva a kortársak minden értetlenségével, dölyfös alkalmatlanságával: „Manapság azonban kegyesség [gondoskodás] nélkül akarnak bátrak lenni" ${ }^{102} \mathrm{stb}$.

\footnotetext{
100 Laozi LXVI, Tőkei 2005, II: 40.

${ }^{101}$ Lásd 46. lábjegyzet.

102 Laozi LXVII, Tőkei 2005, II: 41.
} 
Az intézményes rendszerekben, az elosztás torzító tendenciáiban megnyilvánuló társadalmi represszió LXXVII. fejezetbeli kritikájával az „ég daójának” - e tekintetben is - kiegyensúlyozott müködési mechanizmusaira hívja fel a figyelmet a következőkben Laozi, s annak követésére indít (mindig): mert ,az ég daoja elvesz attól, akinek túlságosan sok van, s gyarapítja azt, akinek elegendője sincs" ${ }^{\prime 103}$. A folyamatok, amelyekbe az ember nem avatkozik deformatíve, a javak eloszlásának tekintetében „méltányosabb” eredménnyel járnak, mint a kényszerítő rendszerek civilizációs törekvéseiben hatók - érthetjük, s érthetjük ekként: már a hatalmi apparátus fenntartásának puszta költségei is fölös tehertételként nehezednek a népre, nemhogy fényüző életmódjának kielégítése.

A ,dao birtokosa” az egyetlen olyan, ki „dúskál”, mégis mind e tetemest, a birtokában levőt (ti. a daót) az egész égalatti boldogulására képes fordítani - irányítja Laozi a figyelmet immár a shengren szerepére -, s teszi ezt „tettel” (wei 為) a szöveg meglepő tanúsága szerint: ,így hát a bölcs ember befolyásol (wei), de nem támaszkodik erre" "104. A tevékeny bölcs képe még árnyaltan is, és minden további, ismerős és jellemző vonása ellenére is (mint: „,sohasem vágyik arra, hogy mutogassa kiválóságát [xian 賢]”105) idegenül hat. Ennek

${ }^{103}$ Laozi LXXVII, Tőkei 2005, II: 43. Vö. Lau 1994: 83: „It is the way of heaven to take from what has in excess in order to make good what is deficient."

104 Laozi LXXVII, Tökei 2005, II: 44. James Legge fordításában a „,bölcs ember” fogalmát e helyen - akárcsak a LX. passzus kulcshelyén - megtoldja egy értelmező kiegészítéssel: ,(ruling)”, azaz „(uralkodó)” (Legge 1891: 104, 119). Ennek oka - minden bizonynyal - a wei-jel tevékenyen ható bölcs megszokottól eltérő attitüdjének azonosítása, egyben fogalmának az (ideálisan tétlen, ám szokásosan tevékeny) uralkodó fogalmához való közelítése. Erről tanúskodik Legge a szöveghez füzött további megjegyzése is, miszerint a bölcs jelen alakja megegyezik a XXV. fejezetben szereplö király (wang) alakjával (Legge 1891: 120). E kommentár azonban már jogos értetlenséget szül, mivel sehol a Laozi-ben nem fordul elő, hogy a wang, mint kitüntetett létező, tevékeny volna. Ennek épp az ellenkezője igaz: talán a XXXVII. fejezet mondja leghangosabban, hogy a „tízezer létező" (wanwu) egyike sem lehet tevékeny (ami a wei-t illeti), legkevésbé pedig a „fejedelmek és királyok” (houwang), akik a daót „megőrizve” hasonulnak ahhoz, s annak hatásában maguk közvetítik azt (a „tízezer létező” felé) - a daót tehát, amely „mindig nem-cselekvő (wuwei)” (Laozi XXXVII, Tőkei 2005, II: 29).

105

Laozi LXXVII, Tőkei 2005, II: 44. Vö. Laozi XXII, Tőkei 2005, II: 24: ,a bölcs ember [...] nem mutogatja magát, ezért ragyog; nem bizonygatja kiválóságát, ezért kiváló (zhang 彰)..."

A mű eredetijében a „kiválóak” (xian) megbecsülésének elmaradását szorgalmazó fejezeten (illetve a LXXV. passzus egy kevéssé látványos szöveghelyén) kívül egyedül ezen a helyen használja a xian terminusát a szerző. A terminus előbbi (ti. III. fejezetbeli) kontextusa - mint jeleztük már - negatív irányú konnotációt társít viszont a fogalom- 
következtében fogalma itt könnyen közelítést nyerhet egy (még fenntartott) politikai aktivitással rendelkező bölcs-uralkodó fogalmához. Ez az uralkodó tett-erejét latba veti, de/és célja - a laozi-i célelvüség különös fonákján értelmezve - a taoista rend helyrebillentése, az „ég daójának” a „nép szívébe” juttatása - az „emberek daójának” minden sanyarúságával szemben. Felidézve azonban a II. és a IX. fejezet tételeinek sürgetését, itt sem mulaszt el figyelmeztetni Laozi: a shengren „beteljesíti müvét, de nem időzik el” ${ }^{\text {"106 }}$ - érthetjük: a hatalomban.

E passzus megfontolásait követő LXXXI. fejezetbeli tanítás alapvetése a shengren odaadó erényalkata, mely odaadást azonban nem lemondásként kell értékelnünk a részéről: a daót közvetíteni - a „bölcs ember” „mindenét” ugyanis - nem jelent veszteséget, csakis többletet a maga (és az égalatti) számára - állítja Laozi. Ezt követően a shengren karakterének meglepő aktívumával (wei), tevékeny hatásával találjuk ismét szembe magunkat: ahogy a passzus bemutatja, a „bölcs ember” „mindent az emberekért tesz (wei)”, illetve „daoja úgy cselekszik (wei), hogy sohasem harcol [sohasem vitázik] (buzheng 不爭)" ${ }^{107}$ A bölcs wei-tevékenységének elismerése újra csak arra az alternáló attitüdre utalhat, amely az egyes fejezetek közti tartalmi modifikációban születik. Annak különbségére ugyanis, amely - ha jellemző példával élünk - az

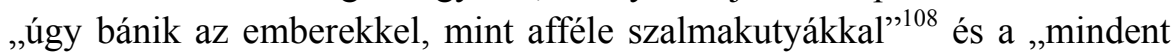
az emberekért tesz" jelen tétele között fennáll. Mindezzel persze nem azt kívánjuk rögzíteni - ellenkezésbe kerülvén az elmondottakkal -, hogy az előbbi tétel hatósugarába eső némely fejezetek ${ }^{109}$ lennének a wuwei tanításának

hoz: olyan tulajdonságot köt hozzá ugyanis, melyet elfedni, elvetni kell - a társadalom békéjét elősegítendő. E „kiválóság” jelen összekötése tehát a „bölcs ember” fogalmával - még akkor is, ha „sohasem vágyik arra, hogy mutogassa [azt]” - ugyancsak jelezheti számunkra a bölcs tanításon belüli alternációját.

106 Laozi LXXVII, Tőkei 2005, II: 44.

107 Laozi LXXXI, Tőkei 2005, II: 45. Akárcsak a LXXVII. fejezet adott pontján, a weitevékenység mint aktívum fennállása politikai beavatkozást, tevőleges kormányzást enged meg az olvasat e szintjén.

Továbbá vö. Laozi VIII, Tökei 2005, II: 19: „A legmagasabb jóság (shangshan 上善) [...] hasznára van minden létezőnek, anélkül hogy küzdene (buzheng)".

108 Lásd 53. lábjegyzet.

109 Ilyen lehet - egyebek mellett - a könyv II. fejezete (Laozi II, Tökei 2005, II: 17). A hasonló szellemben megfogalmazódó tételek árnyaltabb olvasatát a Zhuangzi lapjain találjuk: ott is kitünik ebben az I/2. passzus (Zhuangzi I.2, Tőkei 2005, II: 59). 
egyedüli letéteményesei, de az utóbbihoz közelítők ${ }^{110}$ legalábbis - úgy tünik - kevésbé tematizálják eszerint tartalmukat ${ }^{111}$.

Megkülönböztetve és kiemelve továbbá az ,égalatti királyának” szent hivatását a fejedelmek - akár - erényes országlásától: a LXXVIII. fejezet abban állapítja meg a wang kivételes erejét, hogy hivatott magára vállalni és viselni országa, az égalatti minden viszontagságát. Az a taoista belátás pedig, miszerint ,a gyenge mindig legyőzi az erőset, a lágy pedig legyőzi a szilárdat"112, arra indítja a shengrent, ${ }^{113}$ hogy újra megfogalmazza e kettőnek, a ,gyengének” (ruo 弱) és a királynak megegyezését: hisz a ,gyenge” „,alulról” is mindig „felülre” kerül - akár a víz; akár a király, mikor befogadja mind a „szerencsétlenséget” (buxiang 不祥). Hogy a wang ereje ,gyengesége”, ,gyengesége" ereje lehet leginkább, ${ }^{114}$ mi sem láttatja jobban, mint a fejezet utolsó, mélyen antikonfuciánus tétele szerinti: az ,egyenes beszéd” (zhengyan 正言) olyan, mint „nem-egyenessé” való ,átfordulása” (fan 反). ${ }^{115}$

Végül - ahogy a LXXIX. passzus szövegében látjuk - a „bölcs ember” mintaadásában elvárásokkal él: ezt fejezi ki a „baloldali rovások” (zuo qi 左契) felmutatása. A shengren felmutatja a mintát ${ }^{116}$, melynek követésére hív, de

${ }^{110}$ Ennek alapesete a XXVII. fejezet lehet (Laozi XXVII, Tökei 2005, II: 26).

111 Sajátos kivételt jelenthet e tekintetben a könyv X. passzusa, melyben Laozi uralkodóbölcse - az ott leírtaknak megfelelően - népe kormányzását a velük való „törődésben” ( $a i$ 愛) alapítja, bár/és eközben a „nem-cselekvést” (wuzhi 無知) éri el - mintegy annak „megértéseként”. A wuzhi terminológiájának problematikussága ellenére J. Legge is nyitott volt egy hasonló értelmezésre fordításában (,without any [purpose of] action”, azaz „a cselekvés [célja] nélkül”) - bár ezt az adott fejezeten belül egy párhuzamos szöveghelyen tette (Legge 1891: 54). A wuzhi persze nem lehet azonos a wuwei-jel, de - ha érvényesítjük a fordítást - a jelentésük aktuálisan megegyező.

112 Laozi LXXVIII, Tökei 2005, II: 44.

113 Szövegszerüségében a shengren által fogalmazott distinkcióban szereplők (ti. ,a föld- és gabonaistenek ura” [sheji zhu 社稷主], ill. ,az égalatti királya” [tianxia wang 天下王]) és a shengren közti viszony minősége e helyen közelebbröl nem meghatározható. Annak formája, ahogy e karakterek - mint elbeszélő és mint elbeszéltek - megjelennek a fejezet sorai közt, inkább eltávolítja a fogalmakat egymástól, az előbbiét az utóbbiakétól: a bölcs eszerint bölcsel, a fejedelem kormányoz, a király az égalatti üdvéért él.

114 Vö. Laozi LII, Tőkei 2005, II: 35: „,megőrizni a gyengét: erő”.

115 Laozi LXXVIII, Tőkei 2005, II: 44. Konfuciusz tanaira való utalásában e tétel nem más - érvénye kétségtelen -, mint a Lunyu kormányzástani módszerét megalapozó zhengming 正名 (,„egyenes nevek”) tanításának direkt inverziója: cáfolata (vö. Lunyu XIII.3, Tőkei 2005, I: 119-120).

116 A LXV. fejezethez hasonlóan a „de birtoklása” itt is - mint „,rovásokét” - „mérték és példa" birtokát jelenti, s ezek iránymutatását (lásd Laozi LXV, Tőkei 2005, II: 40). 
szükségét nem kényszeríti ${ }^{117}$ - olvashatjuk -, hisz úgy lehet: az emberek úgyis követni fogják, ha fölös beavatkozással nem téríti el őket. Az, aki követeléseit behajtani mindig kész ellenben - és így uralkodik -, híján van a dao erejének - mondja Laozi -, pedig ,a nagy kormányzáshoz nem kell erőszak”"118.

\section{Egybetartó utak}

A LXXII. fejezet tömör, mégis átfogó: esszenciális megfogalmazása a laozi-i tanítások kormányzásra és a „bölcs ember” hatalomgyakorlatára vonatkozó tételeinek. Minden kormányzás, minden hatalom csak akkor lehet teljes, kívánt és tartós, ha megfelelően-egészen korlátozza magát kényszerintézményeiben, erőpolitikájában, s egyáltalán a háttérbe húzódik, a nép mindennapi életébe be nem avatkozik - hirdeti Laozi. Ellenkező esetben - teszi még hozzá - ,zaklatását” megelégelve e hatalom ellen fordul a nép. Ezzel összhangban a „,bölcs ember” is - aki a hatalom letéteményese, látjuk - a háttérben maradó, előkelőségéről, kiváltságokról lemondó vezetője taoista világának. Hogy maga bölcsességét, erejét ismeri viszont, szerepét is ezáltal, ugyanúgy erényéhez tartozik, akárcsak visszavonulása: nemes volta így lehet csak teljes.

Ami az ,igazán nagy hatalmat” (dawei 大威) illeti még, a laozi-i eszményt mint fogalmat könnyen párhuzamba állíthatjuk a XLI. fejezet metaforikus daoképzeteivel, a „legnagyobb négyszöggel” (dafang 大方), a ,hatalmas edénnyel” (daqi 大器) stb. ${ }^{119}$ Mindezek egyformán olyasvalamik, melyek úgy merítik ki fogalmukat, hogy valójában meghaladják azt. A dao olyan hatalmas - mondja Laozi -, hogy nem is vesszük észre. ${ }^{120}$ Ugyanígy az ,igazán nagy hatalom" is olyan hatalmas, hogy nem is vesszük észre - bár jelen van, és mindig $^{121}$ : ezért tarthat kevés számot a sikerre az az interpretáció, amely nem számol e párhuzamossággal, amely nem fogadja be a paradoxont, amely a

117 Vö. Laozi LVIII, Tökei 2005, II: 37: „a bölcs ember (shengren) négyszöget formál, de nem nyeseget (másokat), sarkot alakít, de nem vág le (másokból), egyenes, de nem feszít meg (másokat), ragyogó, de nem vakít el (másokat)".

118 Laozi XXVIII, Tökei 2005, II: 26. Vö. Schwartz 1998: 193.

119 Laozi XLI, Tökei 2005, II: 31.

${ }^{120}$ Laozi XIV, Tőkei 2005, II: 21: „Nézem és nem látom, ezért a neve: észrevehetetlen ( $y i$ 夷). [...] Szembe megyek vele s nem látom az elejét, utánamegyek s nem látom a végét”; Laozi XXXIV, Tökei 2005, II: 28: „Minden létező (wanwu) visszatér hozzá [...], de nem tudják, hogy uruk van. Megérdemli tehát a Hatalmas nevet”; stb.

121 Vö. a daóra vonatkoztatva pl. Laozi VI, Tőkei 2005, II: 18. 
„legnagyobb hatalmat” ténylegesen semmi-hatalomnak érti tehát. A dao esetében ugyanis aligha lehetne állítani, hogy annyira hatalmas, hogy már nincs is, vagy - ami ugyanaz lehet - annyira kicsiny, hogy már nincs is. És ezt az „,gazi hatalom” esetében sem tehetjük meg: hiszen látható, a dao és a „legnagyobb hatalom" közti analógia az értelmezést ebben az irányban befolyásolja.

A Daodejing leghíresebb archaizmusa, a LXXX. fejezetbeli, mind végre is világos képet fest Laozi idilli „országáról”, annak berendezkedéséről: intézménynélküliségéröl. A tan minden elitizmusa végét jelöli annak a közösségnek az ideális leírása, melyben a taoista egyszerüség, a ziran érvénye teljes valójában kifejezésre jut: s ,a nép magától visszatér a faragatlan fa állapotába

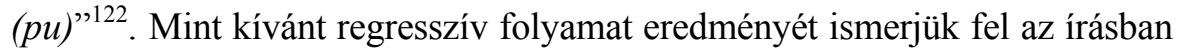
szereplö kitételek (és a kortörténeti egyeztetés ${ }^{123}$ ) nyomán feltáruló anakronizmust: civilizatórikus eszközök bősége áll vagy állhat az „ország” népe rendelkezésére ugyanis - taoista gondtalanságukban mégis elhagyják azok használatát.

A folyamat hangsúlyozását azért látjuk indokoltnak, mert bár az idillikum leírása időtlenséget sugall, annak elérésére tett indítvány (ti. „legyen úgy”) időbeliséget feltételez: a megvalósulás mozzanatait ugyanis. Ennek lépései és feltételei maga a taoista kormányzástan, ahogy Laozi - ha heterogén szövegszerüségében is, láttuk - müve többi részében fejezetről fejezetre kifejtette: megrajzolva a shengren áldásos szerepét, feltünését, majd tovatünését. E folyamat utolsó momentumaként a bölcs-uralkodó „visszavonulását”" ${ }^{\text {"24 }}$ találjuk tehát, amely egyben az égalatti („országainak”) egyszerü „maga-olyanságába” való visszatérését, az idillikum - remélt - időtlenségének eljövetelét, a nép további háborítatlan, felemelő nyugalmát jelenti: mindazt, amit a jelen fejezet áhít.

A passzus párhuzamos-ellentétes szerkezetet követve fejti ki kezdetben „ellentételező”, azt követően „tételező” elemekkel társított motívumsorozatát a társadalmi-technikai kezdetlegesség említett egyszerüségéhez való visszatérésről. Ennek főbb pontjai - kezdve az előbbivel: (1) a „kicsiny ország” fa-

Laozi LVII, Tőkei 2005, II: 37. Lásd még Laozi XXVIII, Tőkei 2005, II: 26.

123 Amint Ecsedy Ildikó is írja $A$ kínai állam kezdetei című művében: „Ez a világkép már a Zhou-ház 周 első uralkodójától kezdve anakronizmus; és az első mitikus »császárok«, a Xia-dinasztia 夏 adószedő hadjáratai óta hiú remény a hadaktól érintetlen, békés világrend. Ilyen világ képét legfeljebb végső menedékként színezgethette a »Hadakozó fejedelemségek« véres kora (i. e. V-III. század) [...]; de a békés és »zsarnoktalan« falu utáni nosztalgia ennél mindenképpen korábbi idők emlékezetéből táplálkozhatott" (Ecsedy 1987: 77).

124 Lásd 81. és 106. lábjegyzet kapcsolt föszövegbeli tartalma. 
lusiassága ${ }^{125}$ központi hatalom nélkül, ahol a ,qi 器 -szerszámok” - akár mint áldozati edények: úri kiváltságok ${ }^{126}$ - használaton kívülre kerülnek; (2) a hosszú távú közlekedésre és hadakozásra szánt eszközök, civilizációs vívmányok, „hajók és kocsik”, ,páncélok és fegyverek” használatának elutasító elvetése, a nép ártatlanságának és elégedett egy helyben maradásának ${ }^{127}$ mutatójaként, egyben zálogaként; (3) a lényegéből fakadóan elitista kínai írásnak - az adminisztráció e legföbb eszközének ${ }^{128}$ és a wen-müveltség hordozójának felhagyása az (írást helyettesítő), ,csomókötözéshez” (jiesheng 結繩) való visszatéréssel. A kialakuló kép pedig a „pozitív” mintázat mentén válik teljessé: (4) a külsőtől és belsőtől nem háborított, egyszerü élet mindennapisága elégedettségtől teli - jóslatszerüen -, benne az emberek megtalálják tehát mindazt, ami boldoggá teszi őket.

Míg a taoizmus belső tendenciáinak dinamizmusa - összegzünk ekképp Laozi tanítására egy eredeti-eklektizáló hatással bírt, s a Daodejing szövegének bizonyos széttartó jellegét erősítette az olvasatban, az elsődleges gondolati teljesítmények szintetizálását követően a „köz iránt elhivatott” - mint diszpozíció, mint magatartásminta - a bölcseleti adekvációban már messze

125 Ecsedy 1987: 79: ,ebben a részletben [ti. a fejezet második felében] fordul elő az egyetlen utalás, amiből ezt a kis világot a faluval azonosíthatják (abban a későbbi korban, amikor a várossal ez már szembeállítható). A »kakaskukorékolás« és »kutyaugatás« [...], azaz a háziállattartás ugyanis már legalább letelepült életmódot jelez, a háziállatnevelés feltételei pedig aligha lehettek meg a korai kis erődökben”.

126 Ecsedy 1987: 77-78.

127 Ahogy a shengren mintaszerüségében, a háborítatlan nép is egy helyben maradó - látjuk: egy helyben maradását elemi világlátása kíséri, mely könnyü kielégüléshez vezet igényei egyszerüségében. Ecsedy azonban másfajta - ám igencsak figyelemreméltó megközelítést javasol a kérdést illetően: „Nem annyira az egy helyben maradás dicsérete ez, hanem egyrészt a kényszerü elhurcoltatás, másrészt a »kiváltságos közlekedés« félelme. A hadba-fogságba-munkára elhurcoltak vagy a menekülők tömegesen, gyalog kényszerültek helyet-hazát cserélni, »messzire menni« már a Zhou-dinasztia győzelme után, s az egész Zhou-kor folyamán többször is, természetesen az eredeti települések pusztulása árán, közösségüket is végveszélybe sodorva. S a »hajók-kocsik« fejedelmi útjain királyi adószedők jártak páncélban-fegyverrel, ahogyan azt a hagyomány más ága örzi” (Ecsedy 1987: 78). Illetve: ,a qivel jelzett edények-hangszerek s más »szerszámok« és a »kocsi-hajó« együttese [...] nyelvi klisé ugyanannak a »bünös« fejedelmi fényüzésnek a kifejezésére, amelytől a Laozi »kis országa« távol akar maradni" (Ecsedy 1987: 79).

${ }^{128}$ Ecsedy 1987: 79. 
túlnőtt a „köz iránt érzéketlenen”: s e szellemi mozgással részben egységesült a tan. A konzisztencia, mely a bölcs egyes tanításbeli szerepei között - lehetőség szerint - adottá vált, épp ennek a gondolati mozdulatnak volt köszönhető: amint a ,visszavonulás” kormányzástani jelentősége is megvilágítja, kritikus időzítése megérteti, hogyan lehetséges szerepegyezés a „nem cselekvő tevékenység” két „oldalán” állók, a (karizmatikus) uralkodó és a (világtól elvonult) „,bölcs ember” között. A Laozi kormányzata nem más ezért - a daón áll, mely ,átfordul” -, mint páratlan képessége és ereje magamaga elhagyásának: az égalatti megnyerésének.

\section{Elsődleges források}

[A nagy tanitás - Daxue 大學] „A nagy tanítás (Daxue).” In: Tőkei Ferenc (ford., vál., jegyz.) 2005. Kínai filozófia. Ókor. Szöveggyüjtemény I. kötet. Budapest: Magiszter Társadalomtudományi Alapítvány, 185-195, 216-217.

[Beszélgetések és mondások - Lunyu 論語] „Beszélgetések és mondások (Lunyu).” In: Tőkei Ferenc (ford., vál., jegyz.) 2005. Kínai filozófia. Ókor. Szöveggyüjtemény I. kötet. Budapest: Magiszter Társadalomtudományi Alapítvány, 57-177.

Chan, Wing-tsit 1963. A Source Book in Chinese Philosophy. Princeton, N. J.: Princeton University Press.

[Laozi 老子 - Daodejing 道德經] „Laozi (Daodejing).” In: Tőkei Ferenc (ford., vál., jegyz.) 2005. Kínai filozófia. Ókor. Szöveggyüjtemény II. kötet. Budapest: Magiszter Társadalomtudományi Alapítvány, 17-50.

Lau, D. C. 1994. Lao-tzu: Tao Te Ching. New York: Alfred A. Knopf, Everyman's Library.

Legge, James 1891. The Texts of Taoism Part I. [The Sacred Books of the East 39.] Oxford: Clarendon Press.

[Mengzi 孟子] „Mengzi.” In: Tőkei Ferenc (ford., vál., jegyz.) 2005. Kinai filozófia. Ókor. Szöveggyüjtemény I. kötet. Budapest: Magiszter Társadalomtudományi Alapítvány, 329-385, 392-398.

[Mozi 墨子] „Mozi.” In: Tőkei Ferenc (ford., vál., jegyz.) 2005. Kínai filozófia. Ókor. Szöveggyüjtemény I. kötet. Budapest: Magiszter Társadalomtudományi Alapítvány, 226-297.

[Változások könyve: Csatolt magyarázatok - Yijing: Xici 易經 繫辭] „Változások könyve: Csatolt magyarázatok (Yijing: Xici).” In: Tőkei Ferenc (ford., vál., jegyz.) 2005. Kínai filozófia. Ókor. Szöveggyüjtemény I. kötet. Budapest: Magiszter Társadalomtudományi Alapítvány, 47-49.

Waley, Arthur 1958. The Way and Its Power: A Study of the Tao Te Ching and Its Place in Chinese Thought. New York: Grove Press.

Weöres Sándor 2001. Lao-ce: Tao Te King. Az Út és Erény könyve. Budapest: Tericum.

[Zhuangzi 莊子] „Zhuangzi.” In: Tőkei Ferenc (ford., vál., jegyz.) 2005. Kínai filozófia. Ókor. Szöveggyüjtemény II. kötet. Budapest: Magiszter Társadalomtudományi Alapítvány, 58-123. 


\section{Felhasznált másodlagos szakirodalom}

Chan, Alan 2000. „The Daode jing and Its Tradition.” In: Kohn, Livia (ed.) Daoism Handbook. Leiden: E. J. Brill, 1-29.

Chen, Ellen M. 1989. The Tao Te Ching: A New Translation with Commentary. St. Paul, Mn.: Paragon House.

Creel, Herrlee G. 1970. What is Taoism? And Other Studies in Chinese Cultural History. Chicago: University of Chicago Press.

Ecsedy Ildikó 1987. A kínai állam kezdetei. Budapest: Akadémiai Kiadó.

Fung, Yu-lan 1983 (1953). A History of Chinese Philosophy. Volume I: The Period of the Philosophers. Princeton, N. J.: Princeton University Press.

Hansen, Chad 1992. A Daoist Theory of Chinese Thought. Oxford: Oxford University Press.

Ivanhoe, Philip J. 2003. The Daodejing of Laozi. Indianapolis: Hackett Classics.

Kaltenmark, Max 1969. Lao Tzu and Taoism. Stanford, Calif.: Stanford University Press.

Kósa Gábor 2013. „Laozi és a Daodejing.” In: Kósa Gábor - Várnai András (szerk.) Bölcselők az ókori Kínában. Budapest: Magyar Kína-kutatásért Alapítvány, 161-185.

Liu, Xiaogan 2009. „Daoism (I): Lao Zi and the Dao-De-Jing.” In: Mou, Bo (ed.) History of Chinese Philosophy. London - New York: Routledge, 209-236.

Maspero, Henri 1978. Az ókori Kína. Budapest: Gondolat Könyvkiadó.

Rand, Christopher C. 1979-1980. „Chinese Military Thought and Philosophical Taoism.” Monumenta Serica 34: 171-218.

Robinet, Isabelle 1997. Taoism: Growth of a Religion. (Translated by Phyllis Brooks). Stanford, Calif.: Stanford University Press.

Robinet, Isabelle 2006. A taoizmus kialakulása és fejlódése. Budapest: Arany Hegy Alapítvány.

Schwartz, Benjamin 1998. „The Thought of the Tao-te-ching.” In: Kohn, Livia - LaFargue, Michael (eds.) Lao-tzu and the Tao-te-ching. Albany: State University of New York Press, 189-210.

Tőkei Ferenc 2005. „A taoizmus alapvetése.” In: Tőkei Ferenc (ford., vál., jegyz.) Kínai filozófia. Ókor. Szöveggyüjtemény II. kötet. Budapest: Magiszter Társadalomtudományi Alapítvány, 11-16.

Várnai András 2011. ,»Egyenes nevek« (Zheng ming). Nyelvelmélet, hatalomtechnika és erénytan a klasszikus kínai bölcseletben.” Magyar Filozófiai Szemle 55.2: 9-31.

Várnai András 2013. „A kínai és a görög gondolkodás »összemérhetőségének“ nehézségeiről.” In: Kósa Gábor - Várnai András (szerk.) Bölcselők az ókori Kínában. Budapest: Magyar Kína-kutatásért Alapítvány, 382-494.

Várnai András 2018. „Taoista nézőpontok a nyelvértelmezésben és értékelméletben II. Vajon kinek szánhatták a taoisták müveiket?” Távol-keleti Tanulmányok 10.1: 63-104.

Vasziljev, Leonyid Sz. 1977. Kultuszok, vallások és hagyományok Kinában. Budapest: Gondolat Könyvkiadó.

Wu, Joseph 1995. „Taoism.” In: Bishop, Donald H. (ed.) Chinese Thought. An Introduction. Delhi: Motilal Banarsidass, 32-58.

Wu, Yi 1989. The Book of Lao Tzu (The Tao Te Ching). San Francisco: Great Learning Publishing Company. 